\title{
Wnt activation protects against neomycin-induced hair cell damage in the mouse cochlea
}

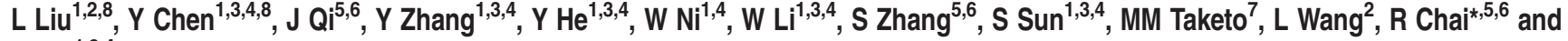 \\ $H$ Li $^{\star, 1,2,4}$
}

Recent studies have reported the role of Wnt/ $\beta$-catenin signaling in hair cell $(\mathrm{HC})$ development, regeneration, and differentiation in the mouse cochlea; however, the role of Wnt $\beta$-catenin signaling in $\mathrm{HC}$ protection remains unknown. In this study, we took advantage of transgenic mice to specifically knockout or overactivate the canonical Wnt signaling mediator $\beta$-catenin in HCs, which allowed us to investigate the role of $\mathrm{Wnt} / \beta$-catenin signaling in protecting $\mathrm{HCs}$ against neomycin-induced damage. We first showed that loss of $\beta$-catenin in HCs made them more vulnerable to neomycin-induced injury, while constitutive activation of $\beta$-catenin in HCs reduced HC loss both in vivo and in vitro. We then showed that loss of $\beta$-catenin in HCs increased caspasemediated apoptosis induced by neomycin injury, while $\beta$-catenin overexpression inhibited caspase-mediated apoptosis. Finally, we demonstrated that loss of $\beta$-catenin in HCs led to increased expression of forkhead box 03 transcription factor (Foxo3) and Bim along with decreased expression of antioxidant enzymes; thus, there were increased levels of reactive oxygen species (ROS) after neomycin treatment that might be responsible for the increased aminoglycoside sensitivity of HCs. In contrast, $\beta$-catenin overexpression reduced Foxo3 and Bim expression and ROS levels, suggesting that $\beta$-catenin is protective against neomycininduced $\mathrm{HC}$ loss. Our findings demonstrate that $\mathrm{Wnt} / \beta$-catenin signaling has an important role in protecting HCs against neomycin-induced $\mathrm{HC}$ loss and thus might be a new therapeutic target for the prevention of $\mathrm{HC}$ death.

Cell Death and Disease (2016) 7, e2136; doi:10.1038/cddis.2016.35; published online 10 March 2016

Inner ear hair cells (HCs) are responsible for hearing. Aminoglycosides can be ototoxic and induce caspasemediated apoptosis in HCs. During mammalian inner ear development, canonical Wnt signaling is critical for otocyst induction and directs the formation of the vestibular organs. ${ }^{1,2}$ Wnt signaling also has an important role in the cochlear $\mathrm{HC}$ development, and knockout of $\beta$-catenin inhibits $\mathrm{HC}$ differentiation from sensory progenitors thus reducing $\mathrm{HC}$ generation. ${ }^{3,4}$ Recently, the Wnt signaling downstream target genes Lgr5 and Axin2 have been reported to mark inner ear $\mathrm{HC}$ progenitors. Lgr5-positive $\mathrm{HC}$ progenitors can self-renew to regenerate $\mathrm{HCs}$ after isolation in vitro and can spontaneously regenerate $\mathrm{HCs}$ after $\mathrm{HC}$ damage in the neonatal mouse cochlea in vivo. ${ }^{5-10}$ Recent studies have also shown that Wnt signaling has dual roles in controlling the proliferation and differentiation of $\mathrm{HC}$ progenitors; ${ }^{3,4}$ however, the role of
Wnt/ $\beta$-catenin signaling in $\mathrm{HC}$ survival and damage protection in the mouse cochlea remains unclear.

In other organs, the $\mathrm{Wnt} / \beta$-catenin signaling pathway has been shown to function in various cell processes, including cellular protection. ${ }^{11-15}$ The pro-survival activity of the Wnt pathway has been reported in many tissues, and is believed to be mediated by the induction of specific anti-apoptotic genes. ${ }^{16,17}$ For example, in retinal ganglion cells Wnt activation reduces apoptosis by increasing the expression of protective growth factors including NT3, BDNF, and NGF. ${ }^{11}$ In the intestine, overexpression of Wnt2a glycoprotein ligand of the Wnt proteins decreases bacterial-induced intestinal epithelial cell death. In the liver, Wnt/ $\beta$-catenin signaling acts as a transcriptional co-activator of hypoxia inducible factor- $1 a$ signaling and has a protective role against hypoxia-induced liver injury. Forkhead box $\mathrm{O} 3$ transcription factor (Foxo3) and

\footnotetext{
${ }^{1}$ Otorhinolaryngology Department of Affiliated Eye and ENT Hospital, State Key Laboratory of Medical Neurobiology, Fudan University, Shanghai, PR China; ${ }^{2}$ Institutes of Biomedical Sciences, Fudan University, Shanghai, PR China; ${ }^{3}$ Laboratory Center, Affiliated Eye and ENT Hospital of Fudan University, Shanghai, PR China; ${ }^{4}$ Key Laboratory of Hearing Medicine of National Health and Family Planning Commission, Shanghai, PR China; ${ }^{5}$ Key Laboratory for Developmental Genes and Human Disease, Ministry of Education, Institute of Life Sciences, Southeast University, Nanjing, China; ${ }^{6}$ Co-innovation Center of Neuroregeneration, Nantong University, Nantong, China and ${ }^{7}$ Department of Pharmacology, Graduate School of Medicine, Kyoto University, Kyoto, Japan

*Corresponding author: R Chai, Co-innovation Center of Neuroregeneration, Key Laboratory for Developmental Genes and Human Disease, Ministry of Education, Institute of Life Sciences, Southeast University, Nanjing 210096, China. Tel/Fax: +86 2583790971 ; E-mail: renjiec@seu.edu.cn

or H Li, Department of Otorhinolaryngology, Affiliated Eye and ENT Hospital of Fudan University, Room 611, Building 9, No. 83, Fenyang Road, Xuhui District, Shanghai 200031, China. Tel: +86 2164377134 669; Fax: +86 21 64377151; E-mail: hwli@shmu.edu.cn

${ }^{8}$ These authors contributed equally to this work.

Abbreviations: ABR, auditory brainstem response; Bio, (2'Z,3'E)-6-Bromoindirubin-3'-oxime; $\mathrm{HC}$, hair cell; OHC, outer hair cell; IHC, inner hair cell; ROS, reactive oxygen species; P, postnatal day; PFA, paraformaldehyde; Foxo3, forkhead box 03 transcription factor; Fox01, forkhead box 01 transcription factor; Sgk1, glucocorticoidinducible kinase; qPCR, quantitative real-time PCR; DAPI, 4,6-diamidino-2-phenylindole; Myosin7a, MyosinVIIA; TUNEL, transferase-mediated deoxyuridine triphosphatebiotin nick end labeling; NAC, antioxidant N-acetylcysteine; Nq01, NAD(P)H dehydrogenase, quinone 1; Sod1, superoxide dismutase 1; Sod2, superoxide dismutase 2; Gsr, glutathione reductase; Cat, catalase; PMSF, phenylmethanesulphonyl fluoride; BIM, Bcl-2-like protein 11; FM1-43, N-(3-Triethylammoniumpropyl)-4-(4-(Dibutylamino) Styryl) Pyridinium Dibromide
}

Received 08.10.15; revised 11.1.16; accepted 25.1.16; Edited by M Agostini 
a

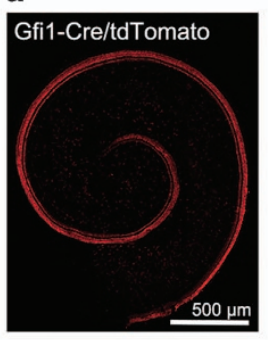

C

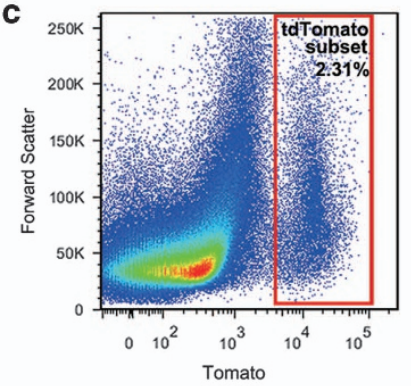

e

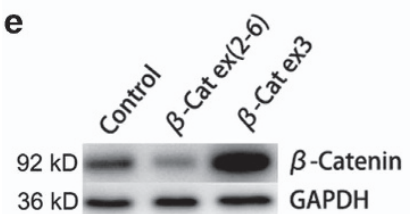

f

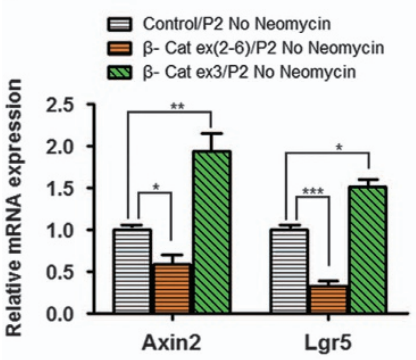

b
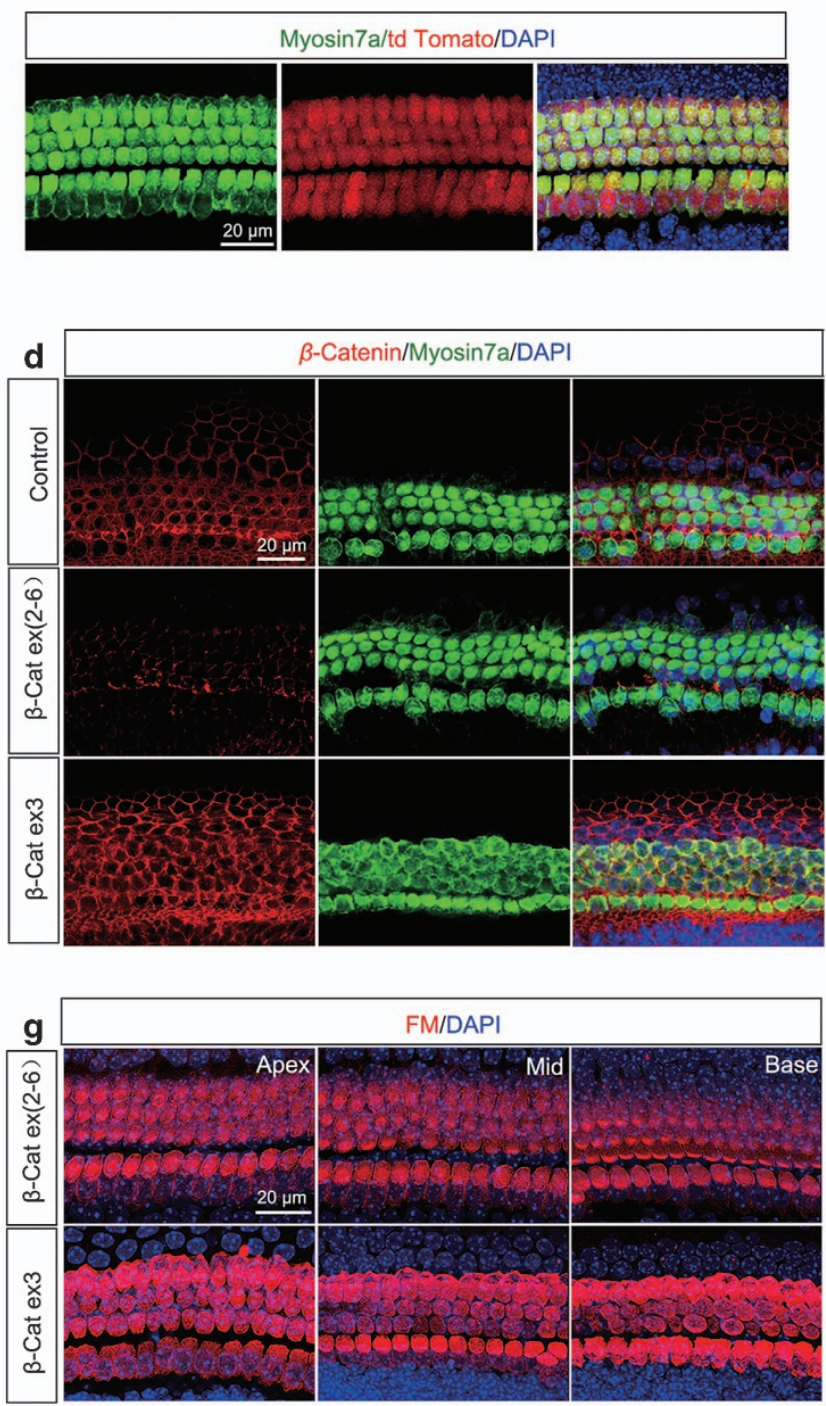

Figure 1 Manipulation of $\beta$-catenin expression in mouse cochlear HCs. (a and $\mathbf{b}$ ) Gfi1-Cre efficiency was tested using Gfi1-Cre/Rosa26-tdTomato mice. Tomato fluorescence showed that Gfi1-Cre activity is similar in inner and outer HCs at all turns in postnatal day (P) 2 Gfi-Cre/tdTomato mice. (c) The tdTomato-positive HCs were isolated using flow cytometry. ( $\mathbf{d}$ and $\mathbf{e}$ ) Western blot and immunofluorescence revealed the increased expression of $\beta$-catenin in Gfi1-Cre/ $\beta$-catenin ${ }^{\text {flox(exon3) }}$ mice and decreased expression of $\beta$-catenin in Gfi1-Cre/ $\beta$-catenin ${ }^{\text {flox(exon2-6) }}$ mice. (f) $\mathrm{qPCR}$ results showed that Wnt target genes, Axin2 and Lgr5, were upregulated in Gfi1-Cre/ $\beta$-catenin ${ }^{\text {flox(exon3) }}$ mice and downregulated in Gfi1-Cre/ $\beta$-catenin ${ }^{\text {flox(exon2-6) }}$ mice. (g) FM1-43 immunofluorescence revealed normal function of mechanotransduction channels in Gfi1-Cre/ $\beta$-catenin ${ }^{\text {flox }(\text { exon3) }}$ and Gfi1-Cre/ $\beta$-catenin ${ }^{\text {flox(exon2-6) }}$ mice. Scale bar: $500 \mu \mathrm{m}(\mathbf{a}) ; 20 \mu \mathrm{m}(\mathbf{b}, \mathbf{d}$ and $\mathbf{g}) .{ }^{*} P<0.05 ;{ }^{* *} P<0.01 ;{ }^{* \star *} P<0.001 . n=5$

Bim, which belong to the BCL-2 family members and are the downstream target gene of Foxo3, ${ }^{18}$ have been reported to regulate the expression of stress-response proteins and to be involved in apoptosis in multiple organs. ${ }^{19-21}$ Overactivation of Wnt signaling inhibits Foxo3-induced apoptosis through upregulation of serum and glucocorticoid-inducible kinase 1 (SGK1), ${ }^{22}$ and overexpression of $\mathrm{Wnt} / \beta$-catenin signaling inhibits Foxo3 signaling in 3,5-diethoxycarbonyl-1,4-dihydrocollidine (DDC)-induced liver injury. ${ }^{23}$ However, the protective role of $\mathrm{Wnt} / \beta$-catenin signaling against neomycin-induced $\mathrm{HC}$ loss in the mouse inner ear has been unclear.

In this study, we used loss-of-function and gain-of-function mouse models to investigate the role of $\mathrm{Wnt} / \beta$-catenin signaling in protecting $\mathrm{HCs}$ against aminoglycoside-induced ototoxicity in the mouse cochlea both in vivo and in vitro. We found that $\beta$-catenin regulates Foxo3 and Bim expression and controls reactive oxygen species (ROS) levels, thus protecting $\mathrm{HCs}$ against caspase-mediated apoptosis after neomycin injury.

\section{Results}

Specifically knockout or overactivate $\beta$-catenin in HCs. $\beta$-Catenin loss-of-function and gain-of-function experiments were performed using Gfi1-Cre/ $\beta$-catenin ${ }^{\text {flox(exon2-6) }}$ and Gfi1-Cre/ $\beta$-catenin ${ }^{\text {flox(exon3) }}$ mice to specifically knockout or overactivate $\beta$-catenin in HCs. Consistent with a previous 
a
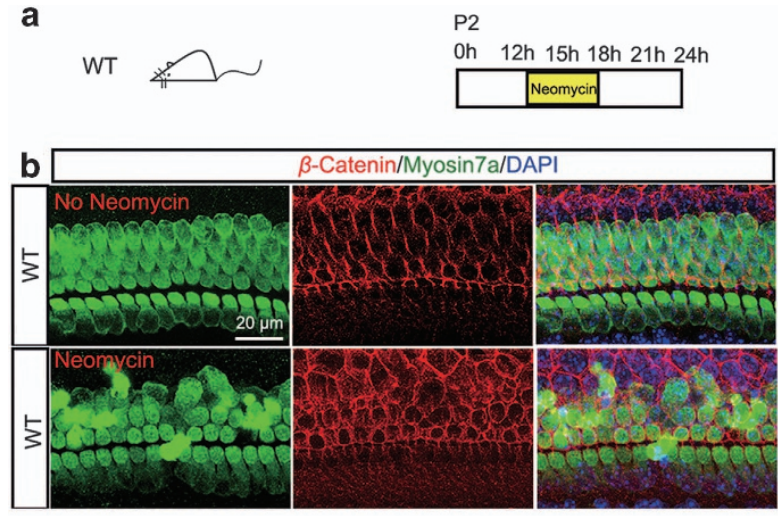

e $\beta$-Cat ex(2-6):Gfi1-Cre or Control
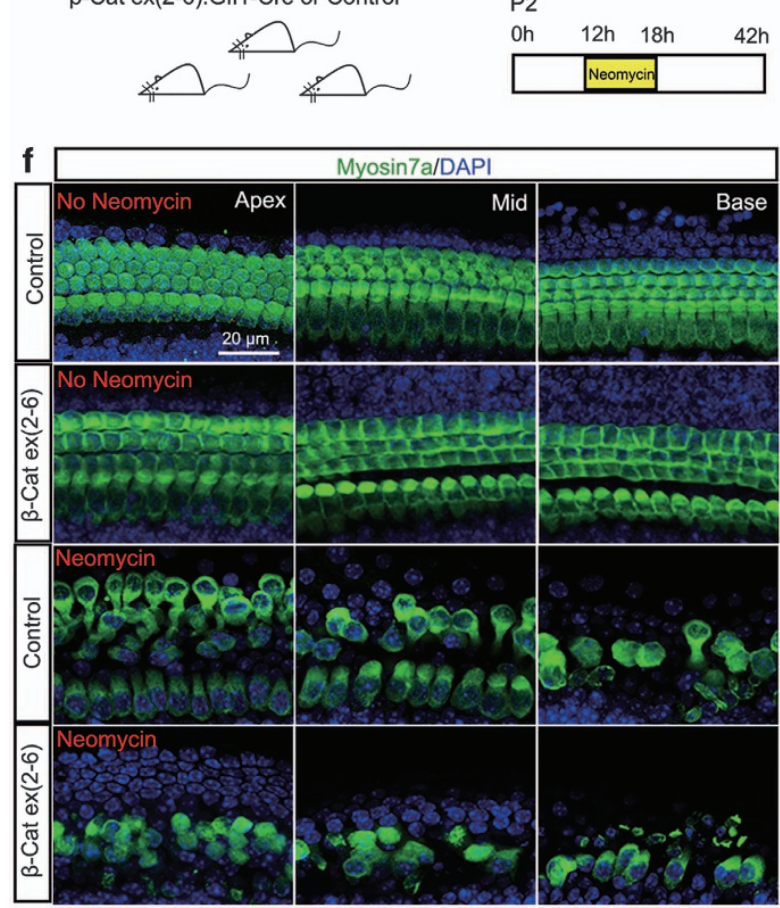
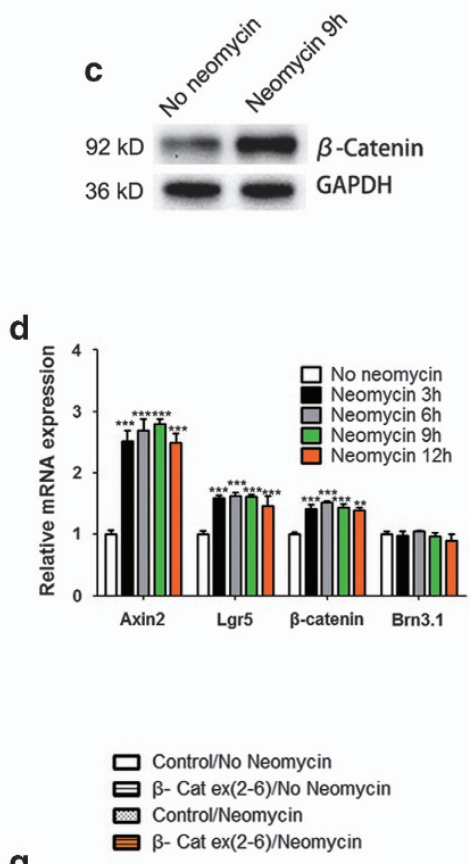

g Control/Neomycin

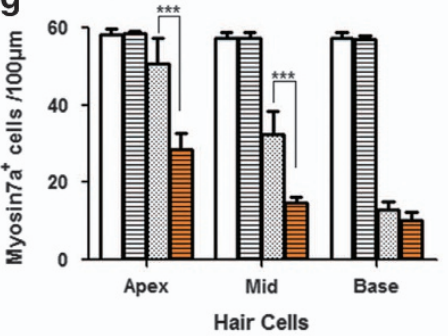

Figure 2 Knockout of $\beta$-catenin makes HCs more vulnerable to neomycin-induced ototoxicity in vivo. (a) The diagram of the assay for (b and c). Cochlear sensory epithelium samples from P2 wild-type mice were dissected out and allowed to recover for $12 \mathrm{~h}$. The samples were treated with 1 mu neomycin for $6 \mathrm{~h}$, allowed to recover for $3 \mathrm{~h}$, and then used for immunostaining and western blot experiments. Samples for qPCR were collected at $0,3,6,9$, and $12 \mathrm{~h}$ after the beginning of neomycin treatment. (b and $\mathbf{c}$ ) Immunofluorescence and western blot revealed the increased $\beta$-catenin expression in the HCs after neomycin injury. (d) qPCR results showed that the expression of $\beta$-catenin and the Wnt target genes Axin2 and $L$ gr5 were significantly upregulated after neomycin injury. ${ }^{* \star} P<0.001,{ }^{\star *} P<0.01, n=5$, versus no neomycin group. (e) The diagram of the assay for ( $\mathbf{f}$ and $\mathbf{g}$ ). Cochlear sensory epithelium samples from P2 Gfit-Cre/ $\beta$-catenin ${ }^{\text {flox }(\text { exon2-6) }}{ }^{\text {mice }}$ were dissected out and allowed to recover for $12 \mathrm{~h}$. The samples were treated with $1 \mathrm{~mm}$ neomycin for $6 \mathrm{~h}$, allowed to recover for $24 \mathrm{~h}$, and then stained with Myosin antibody. Littermates lacking the Gfi1-Cre allele were used as controls. (f and $\mathbf{g}$ ) $\beta$-Catenin knockout mice had significantly greater $\mathrm{HC}$ loss than control mice in the apical and middle turns of the cochlea after neomycin treatment in newborn mice. Scale bar $=20 \mu \mathrm{m} .{ }^{* \star *} P<0.001,{ }^{* \star} P<0.01, n=5$

report, ${ }^{24}$ we found that Cre is activated in $98.76 \pm 0.33 \%$ of the $\mathrm{HCs}$ and Cre activity is similar among the three turns by using Gfi1-Cre/Rosa26-tdTomato mice (Figures 1a and b). Immunohistochemistry results demonstrated that $\beta$-catenin expression in $\mathrm{HCs}$ was decreased in Gfi1-Cre/ $\beta$-catenin flox(exon2-6) mice and increased in Gfi1-Cre/ $\beta$-catenin flox(exon3) mice (Figure 1d). To further test the $\beta$-catenin knockout or overactivation efficiency in $\mathrm{HCs}$, we generated

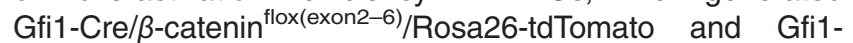
Cre/ $\beta$-catenin ${ }^{\text {flox(exon3)/Rosa26-tdTomato mice and isolated }}$ the tdTomato-positive HCs using flow cytometry (Figure 1c).
Western blot results revealed that the protein expression of $\beta$-catenin in $\mathrm{HCs}$ was significantly decreased

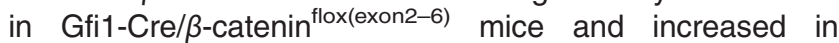
Gfi1-Cre/ $\beta$-catenin ${ }^{\text {flox(exon3) }}$ mice (Figure 1e). The activation level of Wnt signaling in HCs was further confirmed by the mRNA expression of the Wnt downstream target genes Axin2 and Lgr5. Quantitative real-time PCR (qPCR) results showed that the mRNA expression of Axin2 and Lgr5 in HCs were both significantly decreased in Gfi1-Cre/ $\beta$-catenin ${ }^{\text {flox }}$ (exon2-6) mice and increased in Gfi1-Cre/ $\beta$-catenin flox(exon3) mice (Figure 1f). Finally, FM1-43, a marker of functional 
a

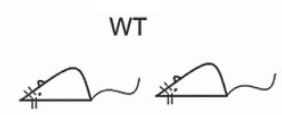

P2
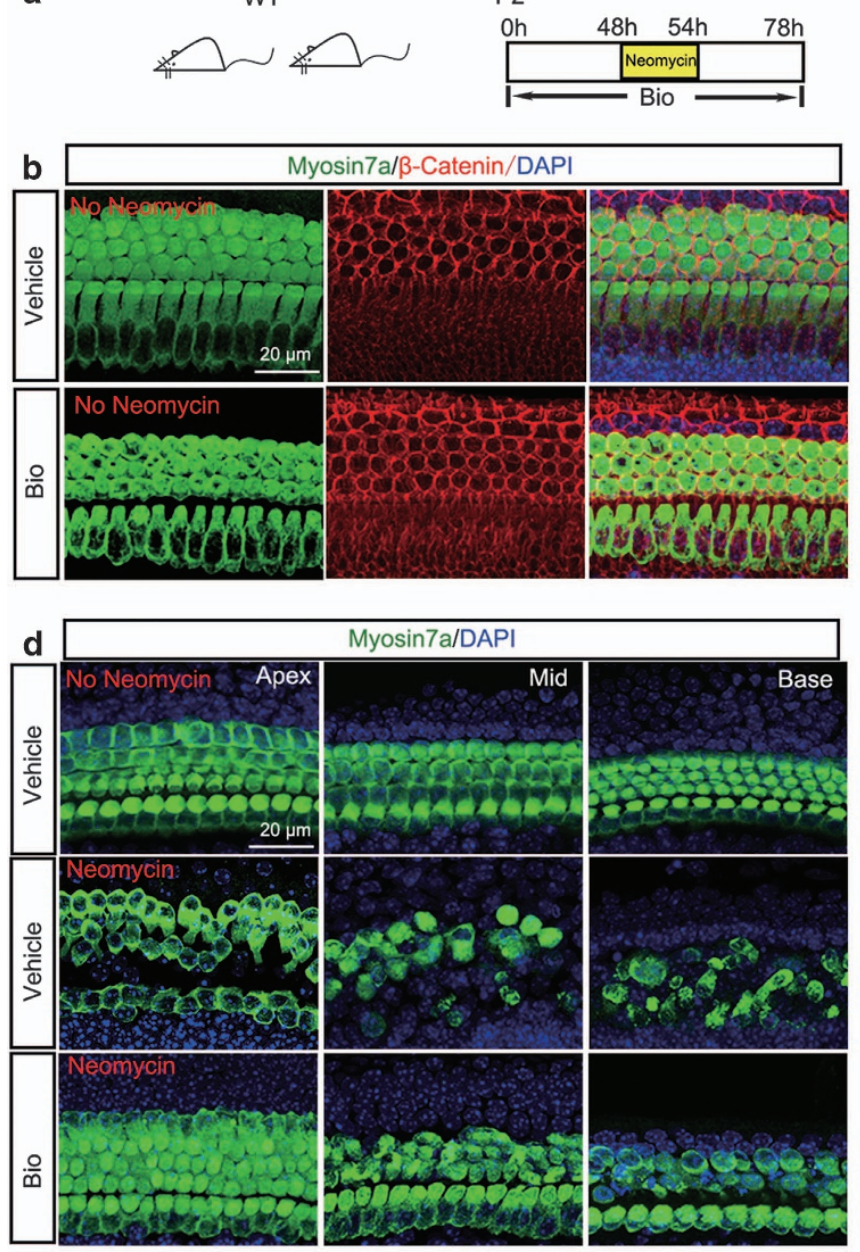

f
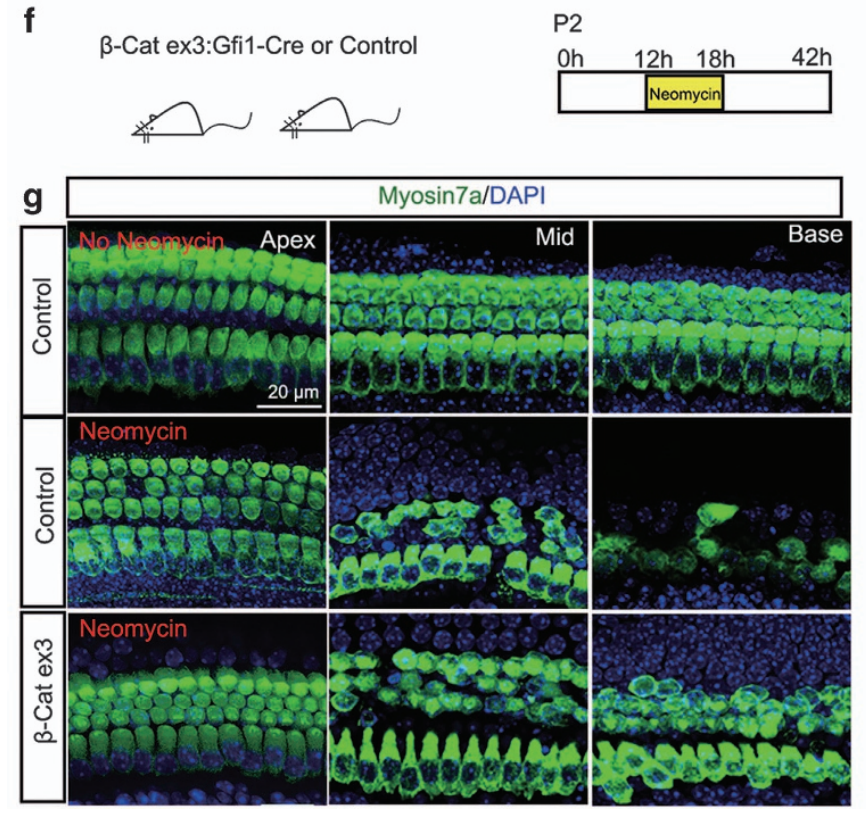

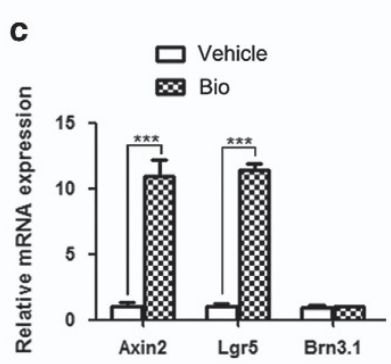

e $\begin{aligned} & \text { Vehicle/No Neomycin } \\ & \text { Vehicle/Neomycin } \\ & \text { Bio/Neomycin }\end{aligned}$
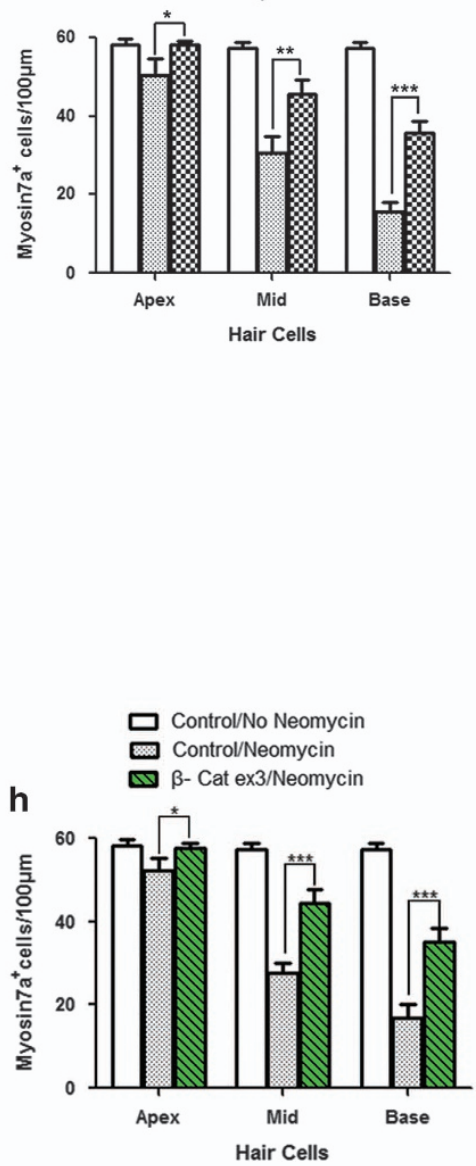
mechanotransduction channels in $\mathrm{HCs}$, was used to detect the mechanotransduction function of $\mathrm{HCs}$ in transgenic mice. FM1-43 staining revealed normal function of mechanotransduction channels in HCs in both Gfi1-Cre/ $\beta$-catenin ${ }^{\text {flox(exon2-6) }}$ and Gfi1-Cre/ $\beta$-catenin ${ }^{\text {flox(exon3) }}$ mice (Figure $1 \mathrm{~g}$ ).

The Wnt/ $\beta$-catenin pathway was activated in the cochlear HCs after neomycin injury. We next explored the expression of $\beta$-catenin and Wnt target genes in the cochlear HCs after neomycin treatment. Both immunofluorescence and western blot results revealed increased $\beta$-catenin expression in the HCs after neomycin injury (Figures $2 b$ and $c$ ). qPCR results showed that the expression of $\beta$-catenin and the Wnt target genes Axin2 and Lgr5 were significantly upregulated after neomycin treatment (Figure 2d). These results demonstrated that the $\mathrm{Wnt} / \beta$-catenin pathway was activated in the cochlear HCs after neomycin injury, indicating that Wnt/ $\beta$-catenin might be a protective physiological mechanism against neomycin injury.

Knockout of $\beta$-catenin makes the HCs more vulnerable to neomycin-induced ototoxicity in vitro. In this experiment, cochlear sensory epithelium samples from postnatal day $(P)$ 2 Gfi1-Cre/ $\beta$-catenin ${ }^{\text {flox(exon2-6) }}$ and control mice were cultured in vitro and treated with neomycin. Without neomycin, there were no reductions in $\mathrm{HCs}$ either in control cochleae or in Gfi1-Cre/ $\beta$-catenin ${ }^{\text {flox(exon2-6) }}$ cochleae (Figures $2 f$ and $g$ ). With neomycin treatment, Gfi1-Cre/ $\beta$-catenin ${ }^{\text {flox(exon2-6) }}$ cochleae had significantly greater $\mathrm{HC}$ loss than control cochleae in the apical and middle turns (Figures $2 \mathrm{f}$ and $\mathrm{g}$ and Supplementary Table 1). This result suggested that $\beta$-catenin has an important role in regulating the sensitivity of cochlear HCs to neomycin-induced injury.

Overactivation of the $\mathrm{Wnt} / \beta$-catenin signaling pathway protects against neomycin-induced HC damage in vitro. To investigate the protective role of $\beta$-catenin against neomycin-induced $\mathrm{HC}$ damage, we used the Wnt agonist Bio and $\beta$-catenin overexpressing transgenic mice in two independent in vitro experiments. First, cochlear sensory epitheliums from P2 wild-type (WT) mice were cultured with Bio $(5 \mu \mathrm{M})$ for $48 \mathrm{~h}$ (Figure $3 \mathrm{a})$. Immunofluorescence results demonstrated upregulated expression of $\beta$-catenin in Biotreated HCs (Figure 3b). qPCR data showed that Bio-treated cochleae had significantly higher expression of the Wnt downstream target genes Lgr5 and Axin2 than the control group (Figure $3 \mathrm{c}$ ). When treated with neomycin in the presence of Bio, Myosin7a staining showed that Bio-treated cochleae had significantly less $\mathrm{HC}$ loss than the control cochleae in all three turns (Figures $3 d$ and $e$ and
Supplementary Table 1), which suggested that Wnt/ $\beta$-catenin signaling could protect $\mathrm{HCs}$ against neomycin-induced damage in vitro.

In a separate experiment, we investigated the protective role of $\beta$-catenin using Gfi1-Cre/ $\beta$-catenin ${ }^{\text {flox(exon3) }}$ transgenic mice. Compared with control cochleae, Gfi1-Cre/ $\beta$-catenin ${ }^{\text {flox(exon3) }}$ cochleae had significantly reduced $\mathrm{HC}$ loss in all three turns after neomycin treatment (Figures $3 \mathrm{~g}$ and $\mathrm{h}$ and Supplementary Table 1), which was consistent with the Wnt agonist treatment and demonstrated that overexpression of $\mathrm{Wnt} / \beta$-catenin protects against neomycin-induced $\mathrm{HC}$ damage in vitro.

Knockout of $\beta$-catenin in HCs leads to partial hearing loss and scattered $\mathrm{HC}$ loss in vivo. To investigate the role of $\beta$-catenin in $\mathrm{HC}$ survival in vivo, we measured hearing function of $\mathrm{Gfi1}-\mathrm{Cre} / \beta$-catenin ${ }^{\text {flox(exon2-6) }}$ mice using pure-tone auditory brainstem response (ABR) and then dissected out the cochlear sensory epithelium for immunohistochemistry staining at P30 and P60 (Figure 4a). The same litter control mice have normal hearing, and no $\mathrm{HC}$ loss was observed at P30 or P60 (Figures $4 \mathrm{~b}$ and d). In Gfi1-Cre/ $\beta$-catenin ${ }^{\text {flox(exon2-6) }}$ mice, we observed a 5-10 dB threshold shift at P30 and a 5-15 dB threshold shift at P60 compared with controls (Figures $4 \mathrm{c}$ and $\mathrm{d}$ ). We also found scattered $\mathrm{HC}$ loss in middle and basal turns, but the total $\mathrm{HC}$ number showed no significant difference compared with controls at P30 and P60 (Figures $4 \mathrm{e}$ and $\mathrm{f}$ ). These results demonstrated that deletion of $\beta$-catenin in $\mathrm{HCs}$ leads to partial hearing loss and scattered $\mathrm{HC}$ loss in vivo.

\section{Overexpression of $\mathrm{Wnt} / \boldsymbol{\beta}$-catenin protects against} neomycin-induced hearing loss and HC loss in vivo. Here, Gfi1-Cre/ $\beta$-catenin ${ }^{\text {flox(exon3) }}$ transgenic mice were given daily subcutaneous injections of neomycin from $\mathrm{P} 7$ to $\mathrm{P} 14$, which is the ototoxic-sensitive period in the cochlea. ${ }^{25}$ At P30 and P60, we measured hearing function and then dissected out the cochlear sensory epithelium for immunohistochemistry staining (Figure 5a). Control mice had significant hearing loss, and the ABR thresholds were significantly increased at all frequencies at both P30 and P60 (Figure 5c). In Gfi1-Cre/ $\beta$-catenin ${ }^{\text {flox(exon3) }}$ mice, the ABR threshold shifts were significantly lower at all frequencies compared with the control littermates at both P30 and P60 (Figure $5 c$ ), suggesting that overexpression of Wnt/ $\beta$-catenin protects against neomycin-induced hearing loss in vivo. Immunohistochemistry results showed that Gfi1-Cre/ $\beta$-cate$\operatorname{nin}^{\text {flox(exon3) }}$ mice had significantly reduced outer hair cell (OHC) loss compared with the control littermates at both P30 and P60 (Figures 5b, d and e and Supplementary Table 2). This demonstrated that overexpression of $\mathrm{Wnt} / \beta$-catenin

\footnotetext{
Figure 3 Upregulating the Wnt pathway protects against neomycin-induced HC damage. (a) The diagram of the assay for (d and e). (b) P2 cochlear sensory epithelium samples were treated with Bio $(5 \mu \mathrm{m})$ for $48 \mathrm{~h}$ in the absence of neomycin. PBS treatment was the vehicle control. Immunofluorescence photo showed upregulated expression of $\beta$-catenin in the Bio-treated group (middle turn, HC layer). (c) The Wnt target genes Axin2 and Lgr5 were upregulated after Bio treatment. (d) Bio-treated cochleae had significantly reduced HC loss after neomycin treatment. (e) The numbers of Myosin-positive cells in the Bio-treated and control cochleae. (f) The diagram of the assay for

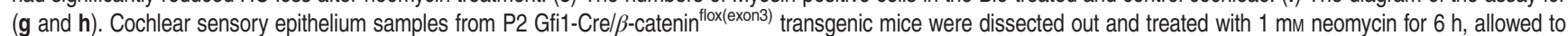
recover for $24 \mathrm{~h}$, and then stained with the Myosin7a antibody. Littermates lacking the Gfi1-Cre allele were used as controls. (g) Representative photo of Myosin-positive HCs after

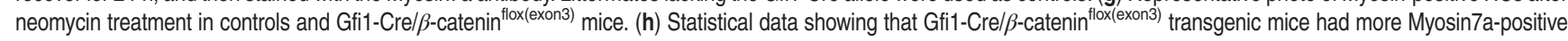
HCs in the apical, middle, and basal turns of the cochlear epithelium. Scale bar $=20 \mu \mathrm{m} .{ }^{\star} P<0.05 ;{ }^{\star \star} P<0.01 ;{ }^{\star \star \star} P<0.001 . n=5$
} 

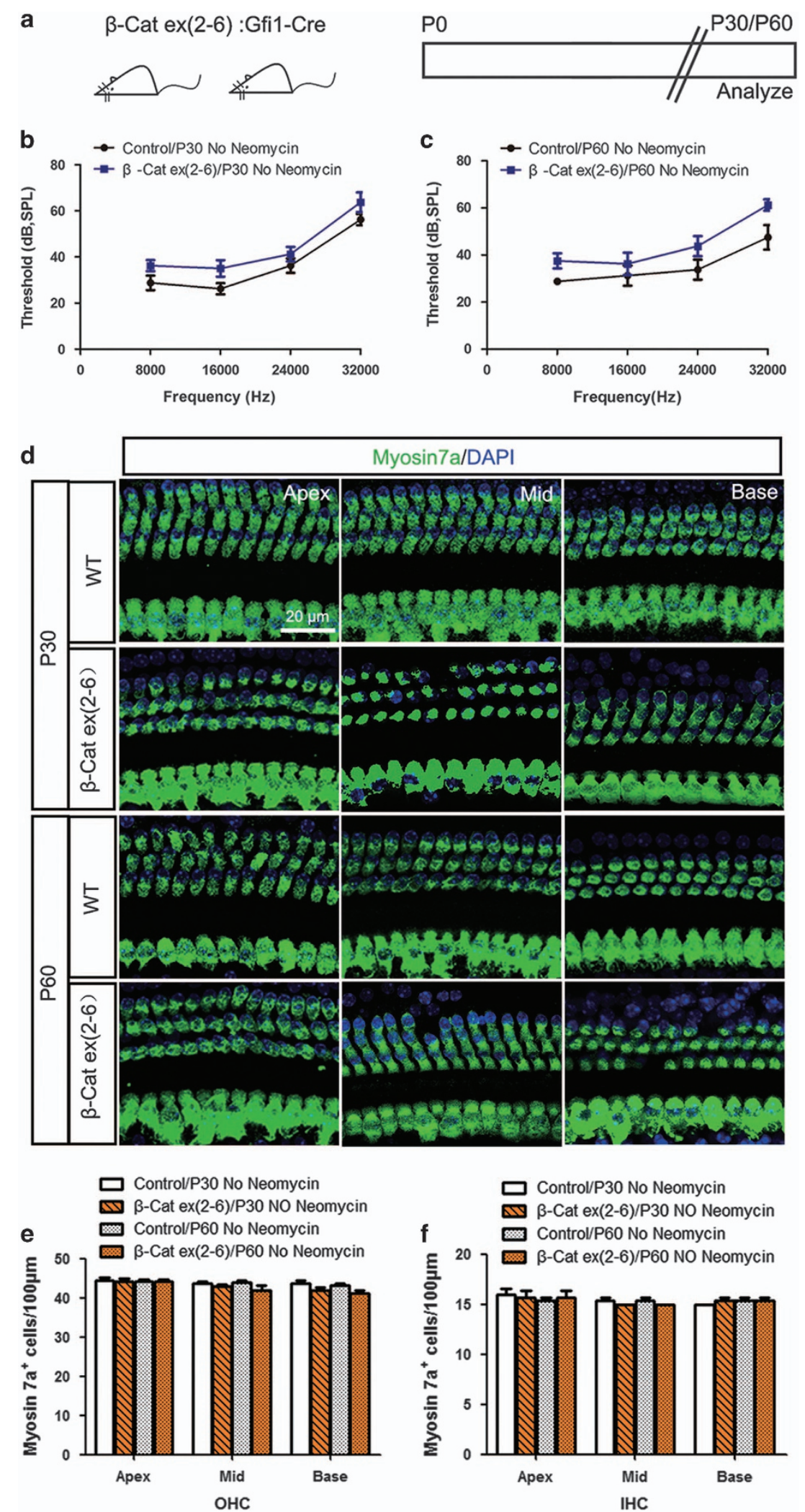

Figure 4 Knockout of $\beta$-catenin in HCs leads to partial hearing loss and scattered HC loss in vivo. (a) The scheme of the assay. Gfi1-Cre/ $\beta$-catenin ${ }^{\text {flox(exon2-6) }}$ transgenic mice were analyzed at P30 and P60 without neomycin treatment. (b and c) Pure-tone ABR data showed partial hearing loss at P30 and P60 in Gfi1-Cre/ $\beta$-catenin flox(exon2-6) mice compared with control groups. (d) Myosin7a immunofluorescence showed scattered HC loss in the middle and basal turns in Gfi1-Cre/ $\beta$-catenin ${ }^{\text {flox(exon2-6) }}$ transgenic mice. (e and f) Statistical data showing that the total $\mathrm{HC}$ number was not significantly different between Gfit-Cre/ $\beta$-catenin ${ }^{\text {flox }(\text { exon2-6) }}$ and control mice. Scale bar $=20 \mu \mathrm{m}$. $n=5$ 

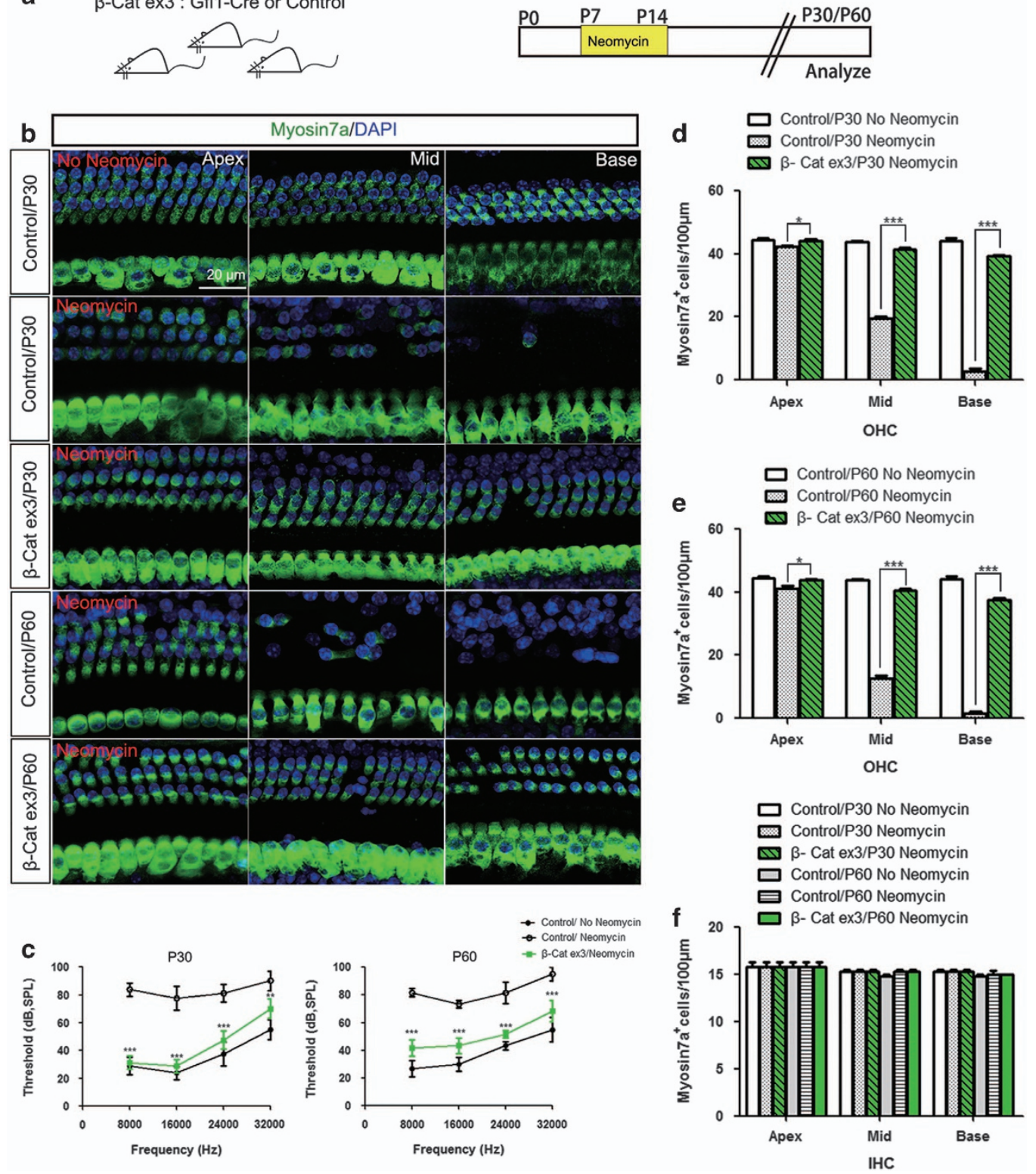

Figure 5 Overexpression of Wnt $/ \beta$-catenin protects against neomycin-induced hearing loss and $\mathrm{HC}$ loss in vivo. (a) The scheme of the assay. Gfi1-Cre/ $\beta$-catenin ${ }^{\text {flox(exon3) }}$ transgenic mice were given daily subcutaneous injections of neomycin $(200 \mathrm{mg} / \mathrm{kg}$ ) from P7 to P14. At P30 and P60, hearing function was measured by using pure-tone ABR and then the cochlear sensory epithelium was dissected out for immunohistochemistry staining. (b) Myosin7a immunofluorescence in P30 and P60 mice after the injection of neomycin or saline. (c) ABR data in P30 and P60 mice. (d) The numbers of Myosin-positive OHC in P30 mice. (e) The numbers of Myosin-positive OHC in P60 mice. (f) The numbers of Myosin-positive IHC in P30 and P60 mice. Scale bar $=20 \mu \mathrm{m} .{ }^{*} P<0.05 ;{ }^{* \star \star} P<0.001 . n=5$

protects against neomycin-induced $\mathrm{OHC}$ loss in vivo. There was almost no inner hair cell (IHC) loss in either Gi1-Cre/ $\beta$ catenin $^{\text {flox(exon3) }}$ mice or control littermates at P30 or P60 (Figures 5b and f).

\section{Wnt/ $\beta$-catenin regulates the caspase-mediated apoptosis} induced by neomycin injection in vivo. Previous studies reported that neomycin kills $\mathrm{HCs}$ through the induction of apoptosis; ${ }^{25-27}$ thus, we investigated the expression of apoptosis-related genes after neomycin injury in vivo. Gfi1-Cre/ $\beta$-catenin ${ }^{\text {flox(exon3) }}$ and Gfi1-Cre/ $\beta$-catenin ${ }^{\text {flox(exon2-6) }}$ mice were treated with neomycin and were killed 3 days after the last injection (Figure 6a). Immunohistochemistry data showed that Gfi1-Cre/ $\beta$-catenin ${ }^{\text {flox(exon3) }}$ cochleae had no parvalbumin/caspase-3 double-positive cells in all three turns, while Gfi1-Cre/ $\beta$-catenin ${ }^{\text {flox(exon2-6) }}$ cochleae had significantly more parvalbumin/caspase-3 double-positive cells in the middle turn compared with the control littermates (Figures $6 \mathrm{~b}$ and $\mathrm{d}$ and Supplementary Table 3). qPCR data

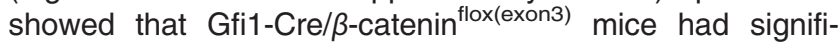
cantly lower expression of the pro-apoptotic genes Casp3, Casp9, Bax, p53, and Apaf1 (Figure 6e), while Gfi1-Cre/ $\beta$ catenin $^{\text {flox(exon2-6) }}$ mice had significantly higher expression of pro-apoptotic genes (Figure 6e). These results demonstrated 
a $\quad \beta$-Cat ex(2-6), $\beta$-Cat ex3:Gfi1-Cre
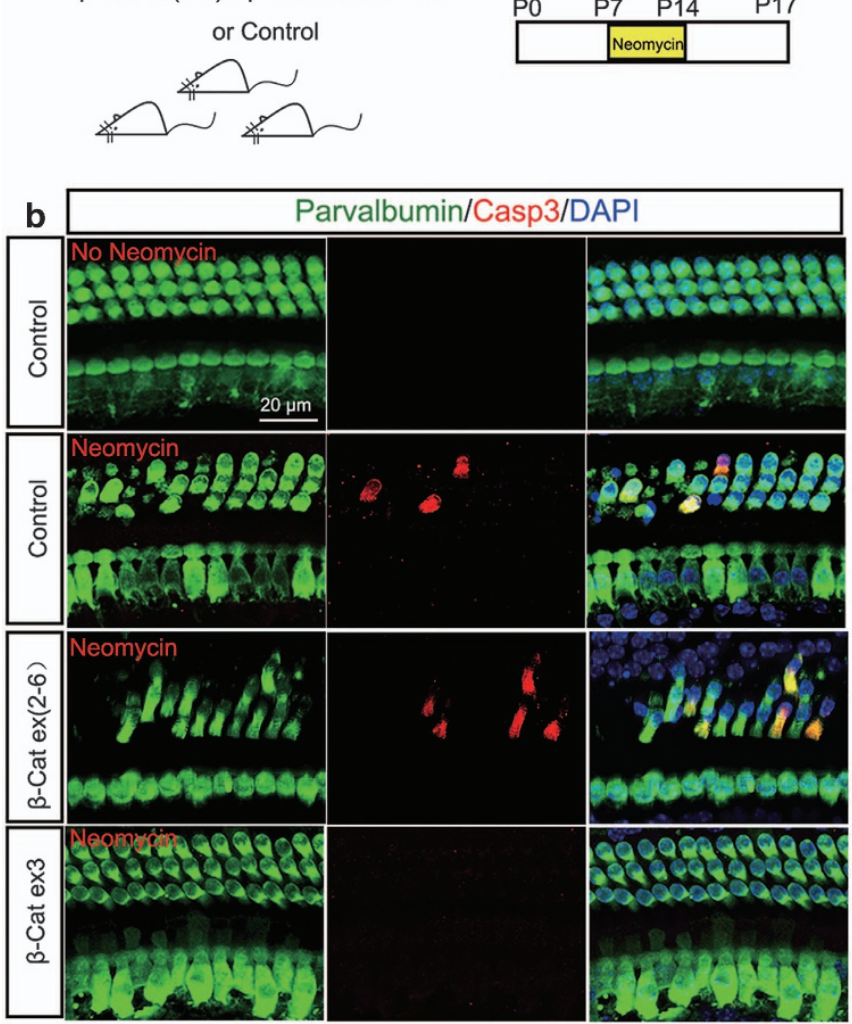

• Control/P17 No Neomycin

C Control/P17 Neomycin

曰 $\beta$ - Cat ex(2-6)/P17 Neomycin

$\left.E^{6}\right]$ - Cat ex3/P17 Neomycin

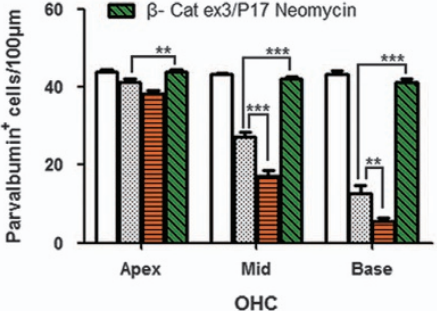

$\mathrm{OHC}$
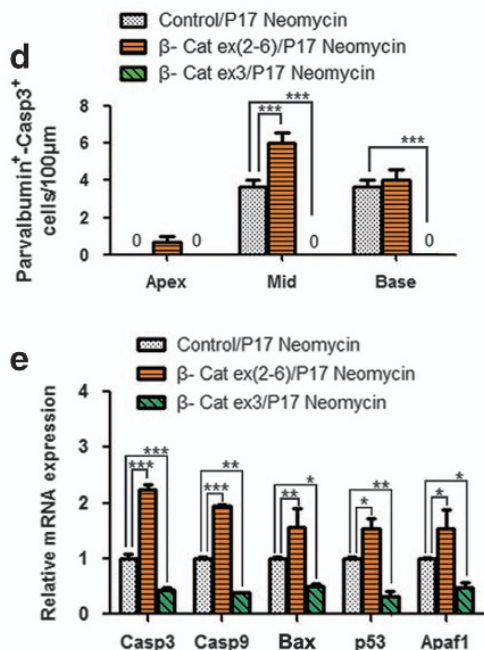

Figure $6 \mathrm{Wnt} / \beta$-catenin regulates the caspase-mediated apoptosis that is induced by neomycin injection in vivo. (a) The scheme of the assay. Mice were given daily subcutaneous injections of neomycin $(200 \mathrm{mg} / \mathrm{kg})$ from P7 to P14. At P17, cochlear sensory epithelium samples were dissected out. The age-matched littermates lacking the Gfi1-Cre allele were used as controls. (b) Representative confocal images of the HC marker parvalbumin and the apoptosis marker cleaved caspase-3 (Casp3) immunofluorescence in P17 mice (middle turn, $\mathrm{HC}$ layer). (c) Parvalbumin-positive HC quantification in OHCs in P17 mice. (d) Statistical data showing that Parvalbumin/Casp3 double-positive cells significantly increased in Gfi1-Cre/ $\beta$-catenin ${ }^{\text {flox(exon2-6) }}$ mice and decreased in Gfi1-Cre/ $\beta$-catenin ${ }^{\text {flox(exon3) }}$ mice. (e) qPCR analysis showed that Casp3, Casp9, Bax, p53, and Apaf1 expression increased in Gfi1-Cre/ $\beta$-catenin ${ }^{\text {flox(exon2-6) }}$ mice and decreased in Gfi1-Cre/ $\beta$-catenin ${ }^{\text {flox(exon3) }}$ mice after neomycin damage. Scale bar $=20 \mu \mathrm{m} .{ }^{*} P<0.05 ;{ }^{* *} P<0.01 ;{ }^{* \star *} P<0.001 . n=5(\mathrm{e})$ or $8(\mathrm{~b}-\mathrm{d})$

that $\mathrm{Wnt} / \beta$-catenin signaling could regulate the caspasemediated apoptosis induced by neomycin injection in vivo.

\section{Caspase-mediated HC apoptosis is regulated by $\mathrm{Wnt} / \beta$ - catenin signaling in $\mathrm{HCs}$ after neomycin injury in vitro. After neomycin treatment in vitro, Gfi1-Cre/ $\beta$ - catenin ${ }^{\text {flox(exon3) }}$ cochleae had significantly fewer TUNEL/ Myosin7a double-positive cells compared with the control littermates, while Gfi1-Cre/ $\beta$-catenin ${ }^{\text {flox(exon2-6) }}$ cochleae had significantly more TUNEL/Myosin7a double-positive cells in the apical and middle turns (Figures $7 \mathrm{~b}$ and $\mathrm{d}$ and Supplementary Table 4). qPCR data showed that the expression of pro-apoptotic genes Casp3, Casp9, Bax, p53, and Apaf1 was significantly reduced in Gfi1-Cre/ $\beta$-catenin ${ }^{\text {flox }}$ (exon3) cochleae compared with controls and was significantly increased in Gfi1-Cre/ $\beta$-catenin ${ }^{\text {flox(exon2-6) }}$ cochleae (Figure 7e). These results demonstrated that $\mathrm{Wnt} / \beta$-catenin signaling in $\mathrm{HCs}$ inhibits the caspase-mediated apoptosis induced by neomycin in vitro.}

Foxo3 expression is regulated by $\mathrm{Wnt} / \beta$-catenin signaling in $\mathrm{HCs}$ after neomycin injury. Previous studies have reported that $\mathrm{Wnt} / \beta$-catenin inhibits the pro-apoptotic transcription factor Foxo3 and protects against oxidative stress-induced apoptosis though downregulation of Foxo3. ${ }^{14,15,28}$ We investigated the Foxo3 expression in neomycin-treated cochleae. At $6 \mathrm{~h}$ after neomycin treatment, intense nuclear Foxo3 staining was observed in control $\mathrm{HCs}$, which is indicative of active Foxo3 signaling in response to neomycin-induced HC damage (Figure 8b). In Gfi1-Cre/ $\beta$ catenin ${ }^{\text {flox(exon3) }}$ cochleae, HCs had significantly reduced Foxo3 staining intensity (Figure 8b). In Gfi1-Cre/ $\beta$-catenin ${ }^{\text {flox(exon2-6) }}$ cochleae, HCs had significantly greater Foxo3 staining intensity (Figure 8b). QPCR and western blot data showed that Foxo3 expression was significantly reduced in Gfi1-Cre/ $\beta$-catenin ${ }^{\text {flox(exon3) }}$ cochleae and significantly increased in Gfi1-Cre/ $\beta$-catenin ${ }^{\text {flox(exon2-6) }}$ cochleae compared with the controls (Figures $8 \mathrm{~d}$ and e). Bim is one of the BCL-2 family members participating in the progress of apoptosis, and is the downstream target gene of Foxo3. ${ }^{18}$ qPCR data revealed that Bim expression was also significantly decreased in Gfi1-Cre/ $\beta$-catenin ${ }^{\text {flox(exon3) }}$ cochleae and increased in Gfi1-Cre/ $\beta$-catenin ${ }^{\text {flox(exon2-6) }}$ cochleae (Figure $8 \mathrm{~d}$ ). These results suggested that after neomycin injury Foxo3 and Bim expression was inhibited when $\beta$-catenin was overexpressed in $\mathrm{HCs}$ and increased 
a

$\beta$-Cat ex(2-6)、 $\beta$-Cat ex3:Gfi1-Cre

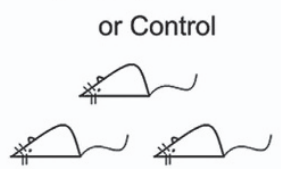

P2

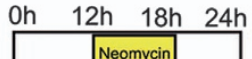

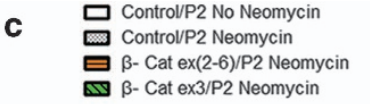
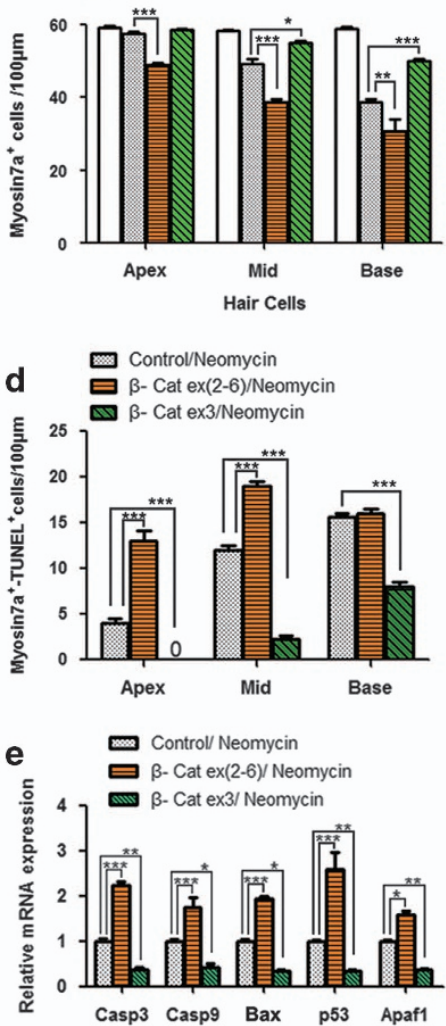

Figure 7 Caspase-mediated HC apoptosis is regulated by Wnt $\beta$-catenin signaling in HCs after neomycin injury in vitro. (a) The scheme of the assay. Cochlear sensory epithelium samples were dissected out from P2 Gfi1-Cre/ $\beta$-catenin ${ }^{\text {flox(exon3) }}$ and Gfi1-Cre/ $\beta$-catenin ${ }^{\text {flox(exon2-6) }}$ mice, then cultured with 1 mm neomycin for $6 \mathrm{~h}$ and allowed to recover for $6 \mathrm{~h}$ before analysis. (b) Representative confocal images of TUNEL and Myosin immunofluorescence (middle turn, $\mathrm{HC}$ layer). (c) Numbers of Myosin-positive HCs after

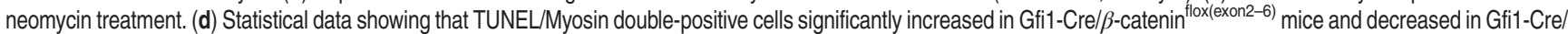

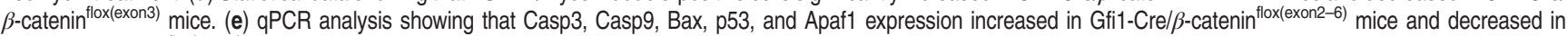
Gfi1-Cre/ $\beta$-catenin ${ }^{\text {flox(exon3) }}$ mice after neomycin damage. Scale bar $=20 \mu \mathrm{m} .{ }^{\star} P<0.05 ;{ }^{* \star} P<0.01 ;{ }^{* \star \star} P<0.001 . n=5$

when $\beta$-catenin was knocked out in HCs. We also noticed that the mRNA expression of Foxo1, which is another member of the Foxo protein superfamily, was not significantly changed (Figure 8d), suggesting that Foxo1 might not be regulated by Wnt signaling in the cochlea.

Furthermore, we investigated the expression level of Foxo3 after $2 \mathrm{~h}$ neomycin treatment, at which time no obvious $\mathrm{HC}$ loss has occurred yet. Immunohistochemistry results showed that HCs had significantly reduced Foxo3 expression in Gfi1-Cre/ $\beta$-catenin ${ }^{\text {flox(exon3) }}$ cochleae and had significantly higher Foxo3 expression in Gfi1-Cre/ $\beta$-catenin flox(exon2-6) cochleae (Figure 8b). qPCR data also demonstrated that the expression of Foxo3 was significantly decreased in Gfi1-Cre/ $\beta$-catenin ${ }^{\text {flox(exon3) }}$ cochleae and significantly increased in Gfi1-Cre/ $\beta$-catenin flox(exon2-6) cochleae (Figure 8c). The expression of Sgk1, which is a $\beta$-catenin target gene and the upstream inhibitor of $\mathrm{FoxO} 3$ activity, ${ }^{23}$ was significantly increased in Gfi1-Cre/ $\beta$-catenin ${ }^{\text {flox(exon3) }}$ cochleae and significantly decreased in Gfi1-Cre/ $\beta$-catenin ${ }^{\text {flox(exon2-6) }}$ cochleae (Figure 8c). Altogether, these results suggested that Foxo3 expression in HCs is regulated by $\mathrm{Wnt} / \beta$-catenin signaling after neomycin injury.
ROS levels in HCs are regulated by $\mathbf{W n t} / \beta$-catenin signaling after neomycin injury. Previous studies reported that Foxo3 is required for the regulation of oxidative stress, ${ }^{18,29}$ and $\mathrm{Wnt} / \beta$-catenin has been reported to protect against oxidative stress-induced apoptosis in many organs. ${ }^{14,15}$ In the mouse cochlea, aminoglycoside-induced accumulation of ROS is closely related to HC apoptosis. ${ }^{30}$ In this experiment, we used MitoSOX Red, a redox fluorophore that selectively detects mitochondrial superoxide, ${ }^{31-33}$ to evaluate mitochondrial ROS generation in HCs after neomycin treatment (Figure 9a). Results showed that Gfi1-Cre/ $\beta$-catenin ${ }^{\text {flox (exon3) }}$ cochleae had significantly fewer MitoSOX/Myosin7a doublepositive cells in all three turns compared with control, and Gfi1-Cre/ $\beta$-catenin ${ }^{\text {flox(exon2-6) }}$ cochleae had significantly more MitoSOX/Myosin7a double-positive cells in the apical turn (Figures $9 \mathrm{~b}$ and $\mathrm{c}$ and Supplementary Table 5). These results suggested that mitochondrial ROS levels in $\mathrm{HCs}$ are significantly reduced in Gfi1-Cre/ $\beta$-catenin ${ }^{\text {flox(exon3) }}$ mice and significantly increased in Gfi1-Cre/ $\beta$-catenin ${ }^{\text {flox (exon2-6) }}$ mice. To find out how Wnt $\beta$-catenin regulates ROS levels in $\beta$-catenin overexpressed/knockout HCs, GPCR was used to investigate the expression levels of several antioxidant enzymes (Nq01, Cat, 

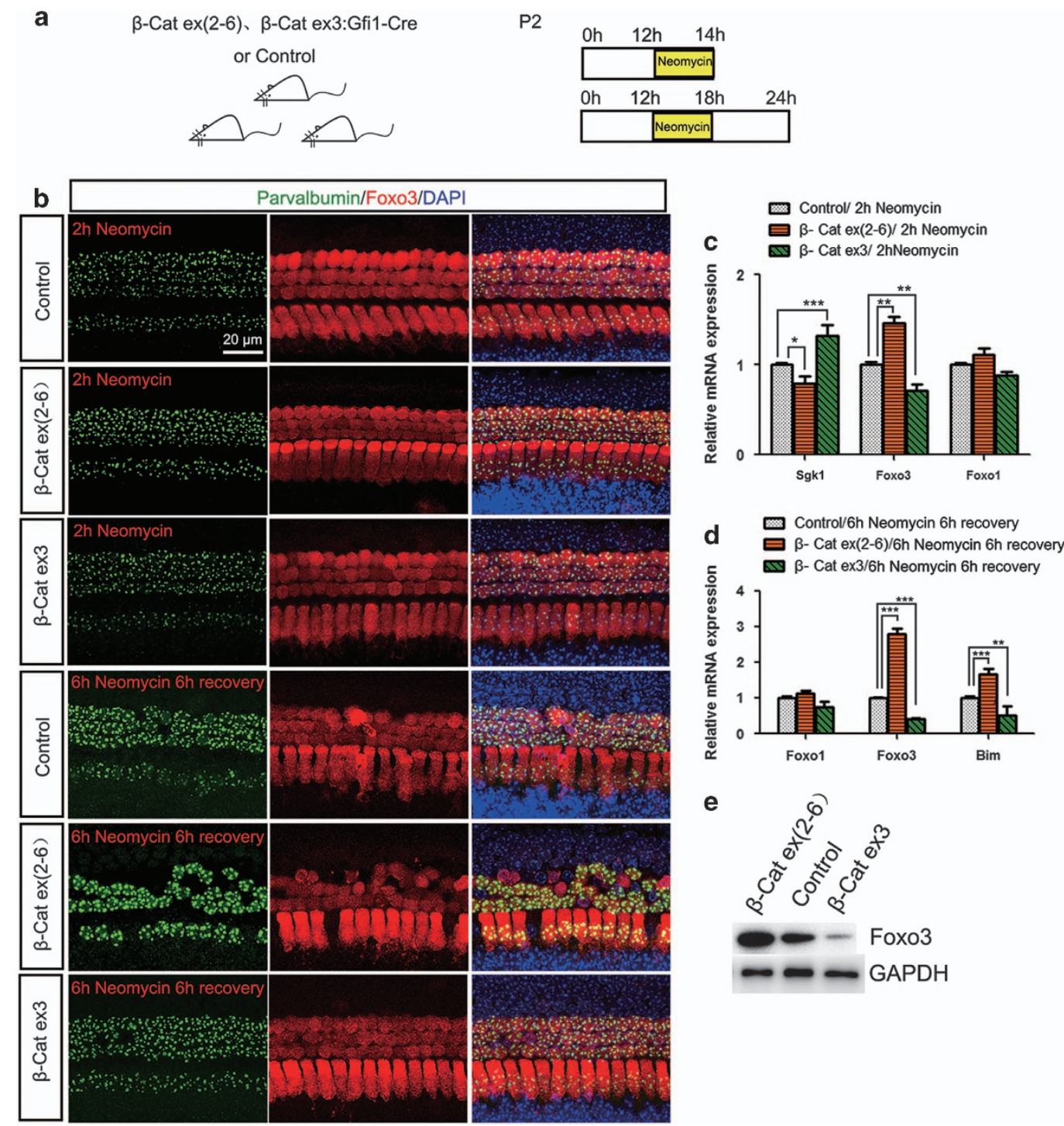

e

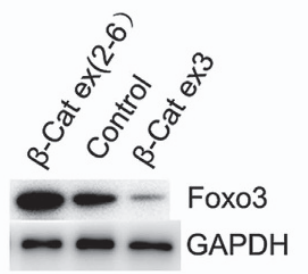

Figure 8 Fox03 expression is regulated by Wnt/ $\beta$-catenin signaling in HCs after neomycin injury. (a) The scheme of the assay. In the first experiment, P2 mouse cochlear epithelium samples were cultured with neomycin for $2 \mathrm{~h}$. In the second experiment, P2 mouse cochlear epithelium samples were cultured with neomycin for $6 \mathrm{~h}$ and then allowed to recover for $6 \mathrm{~h}$ before analysis. (b) Parvalbumin and Fox03 immunofluorescence showed that Foxo3 expression increased in Gfi1-Cre/ $\beta$-catenin ${ }^{\text {flox }(\text { exon2-6) }}$ mice and decreased in Gfi1-Cre/ $\beta$-catenin ${ }^{\text {flox(exon3) }}$ mice after neomycin damage (middle turn, HC layer). (c and d) qPCR data showed the mRNA expression level of Sgk1, Foxo3, Foxo1, and Bim

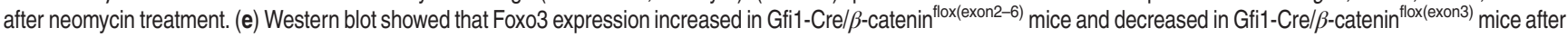
neomycin damage. Scale bar $=20 \mu \mathrm{m} .{ }^{*} P<0.05 ;{ }^{* \star} P<0.01 ;{ }^{\star \star \star} P<0.001 . n=5(\mathbf{b}, \mathbf{c}$, and $\mathbf{e})$ or 8 (d)

Sod1, Sod2, and Gsr). Results showed that antioxidant genes expression, including Sod2, Cat, and Gsr, were significantly increased in Gfi1-Cre/ $\beta$-catenin ${ }^{\text {flox }(\text { (exon2-6) }}$ mice but significantly decreased in Gfi1-Cre/ $\beta$-catenin ${ }^{\text {flox(exon3) }}$ mice (Figure 9d). All of these results demonstrated that $\mathrm{Wnt} / \beta$-catenin signaling regulates neomycin-induced ROS accumulation in HCs.

Antioxidant treatment rescues $\beta$-catenin deficiencyinduced HC loss after neomycin injury. To further investigate whether the increase in ROS levels contributes to the increased injury sensitivity to aminoglycosides of $\beta$-catenin-deficient $\mathrm{HCs}$, the antioxidant $\mathrm{N}$-acetylcysteine (NAC), which is a reduced glutathione provider and a direct scavenger of reactive oxygen intermediates, ${ }^{34}$ was used to treat the explant cultured cochlea with neomycin injury. After NAC treatment, HC loss dramatically decreased in both Gfi1-Cre/ $\beta$-catenin ${ }^{\text {flox(exon2-6) }}$ and control mice, and the number of surviving $\mathrm{HCs}$ was not significantly different between Gfi1-Cre/ $\beta$-catenin ${ }^{\text {flox }(e x o n 2-6)}$ and control mice (Figures 10b and c). Moreover, MitoSOX Red immunofluorescence showed that ROS levels significantly decreased in $\mathrm{HCs}$ of Gfi1-Cre/ $\beta$-catenin ${ }^{\text {flox(exon2-6) }}$ mice after NAC treatment (Figures $10 \mathrm{e}$ and $\mathrm{f}$ ), suggesting that the rescue of the HCs was associated with a decrease in oxidative stress. Together, these results showed that antioxidant treatment successfully rescued the $\beta$-catenin deficiency-induced $\mathrm{HC}$ loss in Gfi1-Cre/ $\beta$-catenin ${ }^{\text {flox(exon2-6) }}$ mice after neomycin injury, and demonstrated that ROS accumulation was the 
a $\beta$-Cat ex(2-6)、 $\beta$-Cat ex3:Gfi1-Cre or Control

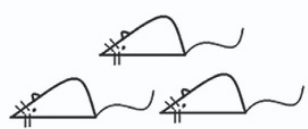

P2

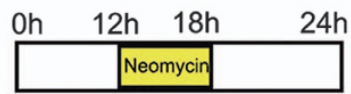

\section{b}
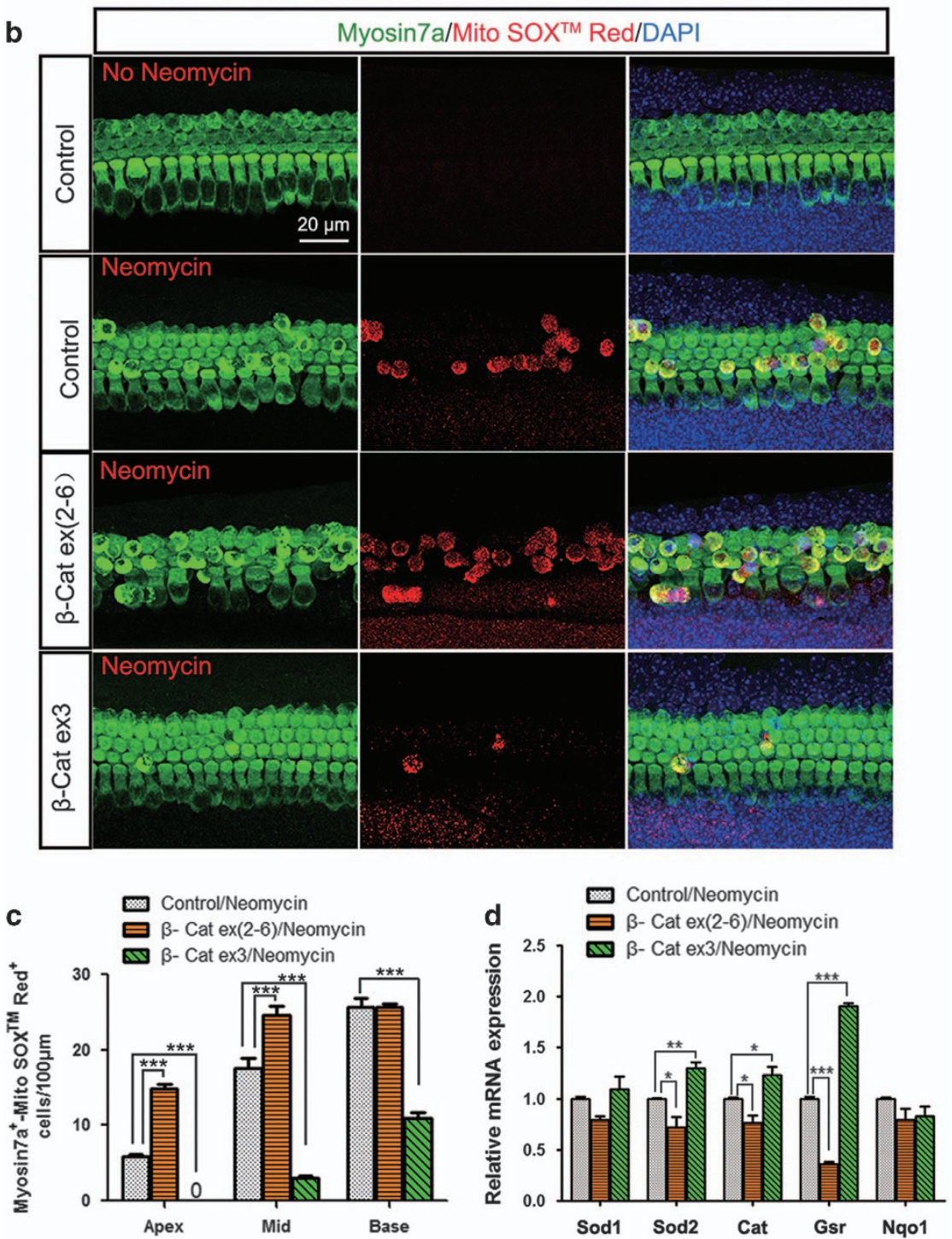

Figure 9 ROS levels in HCs are regulated by Wnt/ $\beta$-catenin signaling after neomycin injury. (a) The scheme of the assay. Cochlear epithelium samples were dissected out and cultured with $1 \mathrm{~mm}$ neomycin for $6 \mathrm{~h}$ and allowed to recover for $6 \mathrm{~h}$ before analysis. (b) Myosin7a and MitoSOX Red immunofluorescence showed that ROS levels increased in Gfi1-Cre/ $\beta$-catenin ${ }^{\text {flox(Ex2-6) }}$ mice and decreased in Gfi1-Cre/ $\beta$-catenin ${ }^{\text {flox(exon3) }}$ mice after neomycin damage (middle turn, HC layer). (c) The numbers of Myosin7a/MitoSOX Red double-positive cells. (d) qPCR results showed that antioxidant gene expression significantly decreased Gfi1-Cre/ $\beta$-catenin ${ }^{\text {flox(exon2-6) }}$ mice but significantly increased in Gfi1-Cre/ $\beta$-catenin ${ }^{\text {flox(exon3) }}$ mice. Scale bar $=20 \mu \mathrm{m}$. ${ }^{\star} P<0.05 ;{ }^{* \star} P<0.01 ;{ }^{* \star} P<0.001 . n=5$

major cause of the high injury sensitivity to aminoglycosides in $\beta$-catenin-deficient HCs.

\section{Discussion}

The role of $\mathrm{Wnt} / \beta$-catenin signaling in cochlear development and $\mathrm{HC}$ regeneration has been extensively studied in the mouse inner ear. Recently, Wnt/ $\beta$-catenin has been reported to be required for $\mathrm{HC}$ differentiation in the mouse cochlea. Knockout of $\beta$-catenin inhibits prosensory cells from differentiating into $\mathrm{HCs}$, but $\beta$-catenin is not required to maintain $\mathrm{HC}$ fate once it is specified. ${ }^{4}$ However, whether Wnt $\beta$-catenin signaling is required for $\mathrm{HC}$ survival has not been investigated. In this study, we observed increased susceptibility of HCs to 
a

B-Cat ex(2-6):Gfi1-Cre or Control
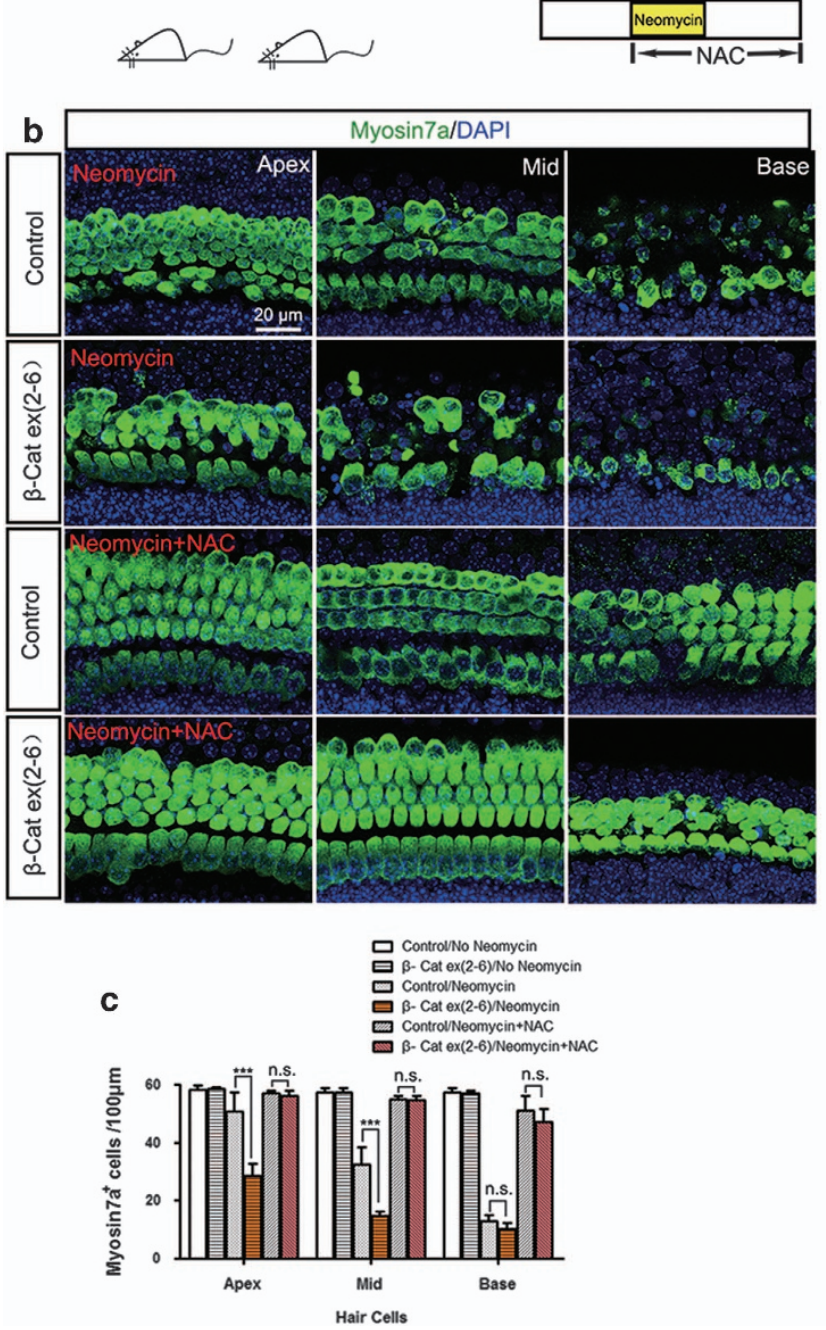

d

$\beta-$ Cat ex(2-6):Gfi1-Cre or Control

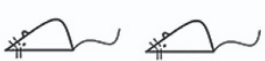

P2

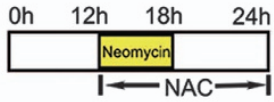

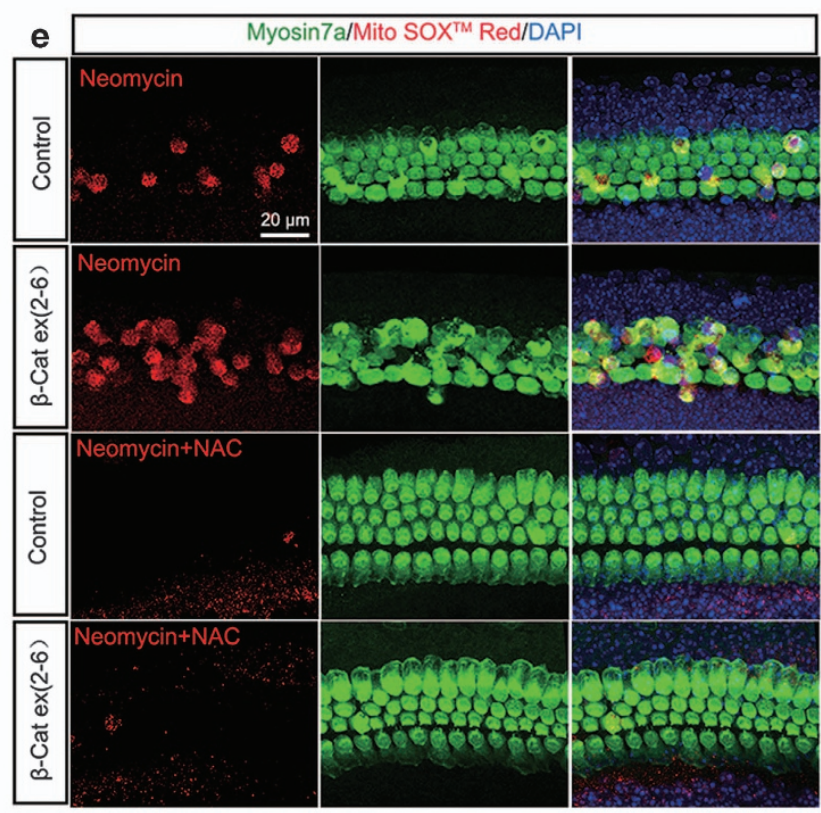

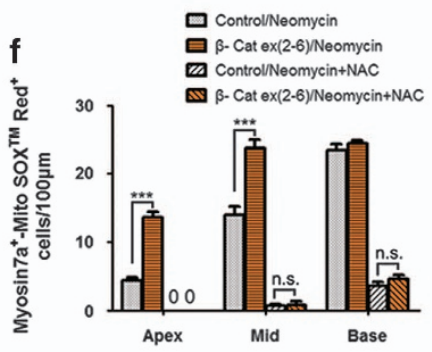

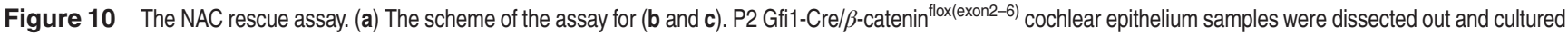
with $1 \mathrm{~mm}$ neomycin for $6 \mathrm{~h}$ with NAC $(20 \mu \mathrm{M})$, then allowed to recover for $24 \mathrm{~h}$ in the presence of NAC before analysis. (b) Myosin7a immunofluorescence showed that NAC treatment rescued $\beta$-catenin-deficient HCs from neomycin injury. (c) Statistical data showing that the number of surviving HCs was not significantly different between Gfi1-Cre/ $\beta$ catenin $^{\text {flox(exon2-6) }}$ and control mice after NAC treatment. (d) The scheme of the assay for (e and f). P2 Gfi1-Cre/ $\beta$-catenin ${ }^{\text {flox(exon2-6) }}$ cochlear epithelium samples were dissected out and cultured with $1 \mathrm{~mm}$ neomycin for $6 \mathrm{~h}$ with NAC $(20 \mu \mathrm{M})$, then allowed to recover for $6 \mathrm{~h}$ in the presence of NAC before analysis. (e) MitoSOX Red immunofluorescence showed that ROS levels significantly decreased in the HCs of Gfi1-Cre/ $\beta$-catenin ${ }^{\text {flox(exon2-6) }}$ mice after NAC treatment. (f) The number of Myosin7a/MitoSOX Red double-positive cells. Scale bar $=20 \mu$ m. ${ }^{* \star}{ }^{\star *} P<0.001$. n.s., no significant difference. $n=5$

neomycin treatment in Gfi1-Cre/ $\beta$-catenin ${ }^{\text {flox(exon2-6) }}$ mice, which indicated that $\beta$-catenin might have an important role in protecting the sensory HCs.

Previous studies reported that several pathways are involved in $\beta$-catenin deficiency-induced cell death, including increased apoptosis of hepatic progenitor cells due to enhanced expression of cleaved caspase- 9 and caspase-3 when $\beta$-catenin expression is blocked, ${ }^{16}$ increased apoptosis in cisplatin-resistant lung adenocarcinoma cells when DKK3 is used to inhibit the Wnt/ $\beta$-catenin pathway, ${ }^{35}$ and increased siLGR5-induced apoptosis when the mitochondrial membrane potential is disrupted in colorectal cancer cells. ${ }^{36}$ In our study, significantly greater $\mathrm{HC}$ loss was observed in $\beta$-catenin knockout cochleae compared with controls after neomycin treatment (Figure 2), which was accompanied by upregulation of the pro-apoptotic transcription factor Foxo3 and its downstream target gene Bim (Figure 8). Foxo3 is a pro-apoptotic transcription factor that regulates the expression of stressresponse proteins and leads to apoptosis in many tissues. ${ }^{19-21}$ In neuronal cells, activation of Foxo3 induces two sequential ROS waves by induction of its transcriptional target Bim. ${ }^{18}$ ROS can oxidize cell constituents, such as DNA, and can lead to DNA damage that activates multiple apoptotic pathways, including caspase-mediated apoptosis and p53-dependent apoptosis. ${ }^{37-39}$ Foxo3 also activates an ROS rescue pathway by inducing Sestrin3, which is responsible for the biphasic ROS accumulation. ${ }^{18}$ Previous studies have reported that $\mathrm{Wnt} / \beta$-catenin protects against oxidative 
stress-induced apoptosis through downregulation of Foxo3. ${ }^{14,15,28}$ In $\beta$-catenin-deficient cochleae, we found that upregulation of Foxo3 expression was accompanied by decreased expression of antioxidant enzymes (Figure 9), increased mitochondrial ROS accumulation (Figure 9), and significantly higher expression levels of Casp3, Casp9, Bax, Apaf1, and p53 (Figures 6 and 7), suggesting that the increased susceptibility of $\beta$-catenin-deficient $\mathrm{HCs}$ to neomycin treatment is attributed to Foxo3 activation and ROS accumulation. The precise role of Foxo3 in the oxidative stress in cochlear HCs needs to be investigated in the future.

Previous studies reported that several genes have protective functions against aminoglycoside-induced $\mathrm{HC}$ loss. Overexpression of XIAP inhibits caspase expression and prevents neomycin-induced $\mathrm{HC}$ death and subsequent hearing loss. ${ }^{25}$ Insulin-like growth factor 1 (IGF-1) protects $\mathrm{HCs}$ from aminoglycosides by upregulating growth-associated protein 43 and netrin $1 .{ }^{40}$ In many organs and cell lines, Wnt/ $\beta$-catenin has been reported to have a protective function against apoptosis. In human HCT116 colon cancer cells, Wnt/ $\beta$-catenin negatively regulates the pro-apoptotic transcription factor Foxo3 and inhibits Foxo3-induced apoptosis. ${ }^{28}$ In the liver, Wnt/ $\beta$-catenin protects against hepatotoxin DDC-induced liver injury and inhibits Foxo3 expression thus inhibiting oxidative stress-induced apoptosis. ${ }^{14}$ In the rat sensory epithelium OC1 cell line, $\mathrm{Wnt} / \beta$-catenin protects the OC1 cells against cisplatin-induced cell death. ${ }^{41}$ Here, we found that after neomycin treatment overexpression of $\beta$-catenin in mouse HCs significantly inhibits the expression of Foxo3 and Bim (Figure 8), enhances the expression of antioxidant enzymes (Figure 9), reduces ROS accumulation (Figure 9), and inhibits caspase-induced apoptosis (Figures 6 and 7), and thus protects HCs against neomycin-induced damage (Figures 3 and 5 ). These results indicate that $\mathrm{Wnt} / \beta$-catenin has an important role in protecting against neomycin-induced $\mathrm{HC}$ damage.

Aminoglycosides are widely used in clinics to treat bacterial infections, but all aminoglycosides have ototoxic side effects, which limit their clinical use. Mammalian sensory HCs have many mitochondria and high oxygen consumption, which makes them very sensitive to oxidative stress, especially when challenged by external stimulation such as noise or aminoglycosides. ${ }^{42}$ Here, we found that knockout of $\beta$-catenin in $\mathrm{HCs}$ increases caspase-mediated $\mathrm{HC}$ apoptosis after neomycin treatment and that overexpression of $\beta$-catenin in $\mathrm{HCs}$ inhibits caspase-mediated $\mathrm{HC}$ apoptosis after neomycin treatment (Figures 6 and 7). Besides the canonical Wnt/ $\beta$-catenin pathway, two $\beta$-catenin-independent pathways have been described, including the Wnt/Ca ${ }^{2+}$ and Wnt/PCP (planar cell polarity) pathways. ${ }^{43,44}$ In the zebrafish lateral line, after exposure to aminoglycosides, dying HCs undergo a transient increase in intracellular $\mathrm{Ca}^{2+}$ that occurs shortly after mitochondrial membrane potential collapse. Inhibition of intracellular $\mathrm{Ca}^{2+}$ elevation mitigates toxic effects of aminoglycoside exposure. ${ }^{45}$ Under physiological conditions, calcium and ROS act as signaling molecules inside the cell and their pathways can interact. However, under pathological conditions dysfunction in either of the systems might affect the other system thus potentiating harmful effects that might contribute to cell death. ${ }^{46}$ The role of non-canonical Wnt signaling in cochlear $\mathrm{HC}$ survival and the role of calcium overload in $\beta$-catenin deficiency-induced increased $\mathrm{HC}$ susceptibility to neomycin need to be investigated in the future.

Previous studies reported that $\mathrm{Wnt} / \beta$-catenin is protective against oxidative stress-induced apoptosis through inhibition of Foxo3 in the liver, bones, and SH-SY5Y cells. ${ }^{14,15,47}$ There are also other papers that suggest that Wnt has the opposite effect on mitochondria. Yoon et al. ${ }^{48}$ reports that increased Wnt signals are a potent activator of mitochondrial biogenesis and ROS generation, leading to DNA damage and acceleration of cellular senescence in primary cells. ${ }^{48}$ This might be because Wnt signaling has diverse functions in different environments and stages, and sometimes these effects are in opposition to each other. For example, promoting proliferation and promoting differentiation are usually two opposing effects, and during embryonic stages Wnt/ $\beta$-catenin signaling promotes proliferation during early mitotic phases of development and also promotes $\mathrm{HC}$ differentiation in the differentiating organ of Corti. ${ }^{3}$ Here, we found that neomycin-induced $\mathrm{HC}$ damage was accompanied by Foxo3 upregulation and mitochondrial ROS accumulation. Knockout of $\beta$-catenin in HCs upregulated Foxo3 expression and increased the accumulation of ROS even more, while overexpression of $\beta$-catenin in $\mathrm{HCs}$ inhibited Foxo3 expression and decreased the accumulation of ROS after neomycin injury. This finding indicates that $\mathrm{Wnt} / \beta$-catenin protects $\mathrm{HCs}$ against neomycin injury by regulating Foxo3 expression and controlling ROS levels.

In summary, we showed that deletion of $\beta$-catenin in $\mathrm{HCs}$ increases neomycin-induced HC loss. Next, we reported that overexpression of $\beta$-catenin in $\mathrm{HCs}$ protects against neomycin-induced $\mathrm{HC}$ loss. Last, we demonstrated that Wnt/ $\beta$-catenin signaling in $\mathrm{HCs}$ regulates Foxo3 expression, antioxidant enzymes, and ROS levels, thus protecting $\mathrm{HCs}$ against caspase-mediated apoptosis after neomycin injury. Our data suggest that $\mathrm{Wnt} / \beta$-catenin signaling is essential for $\mathrm{HC}$ protection against neomycin-induced $\mathrm{HC}$ loss, and thus might be a new therapeutic target for the prevention of aminoglycoside-induced $\mathrm{HC}$ death.

\section{Materials and Methods}

Mouse models and treatments. We used C57BL/6 J WT mice and transgenic mice in the C57BL/6 J background. $\beta$-Catenin ${ }^{\text {flox(exon3) }}$ mice $^{49}$ were generously provided by Mark Taketo (Kyoto University, Kyoto, Japan), $\beta$-catenin ${ }^{\text {flox(exon2-6) }}$ mice ${ }^{50}$ were ordered from The Jackson Laboratory (Bar Harbor, ME, USA; JAX number 004152), Rosa26-tdTomato mice ${ }^{51}$ were ordered from The Jackson Laboratory (JAX number 007914), and Gfi1-Cre mice ${ }^{24}$ were generously provided by Lin Gan (University of Rochester, Rochester, NY, USA). For $\beta$-catenin ${ }^{\text {flox(exon2-6) }}$ mice, Cre-induced recombination at the LoxP sites flanks exons 2-6 of $\beta$-catenin, and Cre activation results in a $\beta$-catenin-null allele. ${ }^{50}$ For $\beta$-catenin ${ }^{\text {flox(exon3) }}$ mice, $\beta$-Catenin:exon3 encodes the GSK3 phosphorylation sites for degradation, and exon 3 is not functionally required for $\beta$-catenin transcriptional activity. Deletion of $\beta$-catenin:exon3 therefore results in increased levels of $\beta$-catenin.

Mice were housed with open access to food and water at the Experimental Animal Center, Shanghai Medical College of Fudan University, China. Postnatal day (P) 0 was defined as the day of birth. Mice received a daily subcutaneous injection of neomycin (200 mg/kg) or sterile saline from P7 to P14. This study was carried out in strict accordance with the 'Guiding Directive for Humane treatment of Laboratory Animals' issued by the Chinese National Ministry of Science and Technology in September 2006. All experiments were approved by the Shanghai Medical Experimental Animal Administrative Committee (Permit Number: 2009-0082). All efforts were made to minimize suffering and reduce the number of animals used. 
Organotypic culture of neonatal mice cochlea. The mice were killed at P2, then the cochlear sensory epithelium was isolated and seeded intact on a glass coverslip coated with Cell-Tak (BD Biosciences, Franklin Lakes, NJ, USA). ${ }^{52}$ The explanted cochleae were treated with $1 \mathrm{~mm}$ neomycin (Sigma-Aldrich, St. Louis, MO, USA) and/or $5 \mu \mathrm{m}$ Bio (Sigma-Aldrich) or $20 \mathrm{~mm}$ NAC (Sigma-Aldrich). PBS was used as the vehicle control.

ABR test. The hearing thresholds of the mice were examined with the ABR test. In this test, changes in the electrical activity of the brain in response to sound were recorded via electrodes that were placed on the scalp of the mice. Animals were anesthetized with ketamine $(100 \mathrm{mg} / \mathrm{kg})$ and xylazine $(25 \mathrm{mg} / \mathrm{kg})$ and placed on a thermostatic heating pad in a sound-attenuating chamber to maintain their body temperatures at $38^{\circ} \mathrm{C}$. Frequency-specific auditory responses were measured using the Tucker-Davis Technology system III (Tucker-Davies Technologies, Gainesville, FL, USA) as previously described. ${ }^{53}$ All ABR tests were performed on mice older than P21.

Tissue preparation for quantitative RT-PCR and western blot. After killing the mice, the otic capsule was immediately isolated, rapidly frozen in liquid nitrogen, and stored at $-70^{\circ} \mathrm{C}$ until further processing. To obtain the total RNA, 10 cochleae were pooled in TRIzol (Invitrogen, Carlsbad, CA, USA) following the manufacturer's instructions. The RNA concentration was measured with a BioRad spectrophotometer (Applied Biosystems, Foster City, CA, USA). cDNA was synthesized from $1 \mu \mathrm{g}$ total RNA by reverse transcription using the GoScript Reverse Transcription System (Promega, Madison, WI, USA) following the manufacturer's protocols. qPCR was performed using GoTaq qPCR Master Mix (Promega) on a Bio-Rad 7500 detection system (Applied Biosystems, Foster City, CA, USA). GAPDH was used as a housekeeping gene for control purposes. Primer sequences are listed in Supplementary Table 6. For protein extraction, 10 cochleae were pooled in $100 \mu$ l RIPA lysis buffer with $1 \%$ PMSF, sonicated, incubated on ice for $30 \mathrm{~min}$, and stored at $-80^{\circ} \mathrm{C}$. Extracts were boiled with $5 \times$ loading buffer, subjected to PAGE (Mini-Protean TGX Systems; Bio-Rad, Hercules, CA, USA), transferred onto an Immobilon-P membrane (Millipore, Bedford, MA, USA), probed with anti-Fox03 antibody (Cell Signaling Technology, Danvers, MA, USA), anti- $\beta$ catenin (BD Biosciences), and anti-GAPDH (Kangchen Biotech, Shanghai, China) and finally incubated with HRP-conjugated secondary antibodies. Signal was detected with the Supersignal West Femto Trial Kit (Thermo Fisher Scientific, Rockford, IL, USA) on a FluorChem M system (ProteinSimple, San Jose, CA, USA).

Immunofluorescence. After fixation, cochlear samples were blocked with $10 \%$ normal donkey serum in $10 \mathrm{~mm}$ phosphate-buffered saline (PBS, pH 7.4) with $0.3 \%$ Triton $\mathrm{X}-100$ for $1 \mathrm{~h}$ at room temperature and then incubated with primary antibody overnight at $4{ }^{\circ} \mathrm{C}$. The next day, the tissues were incubated for $2 \mathrm{~h}$ at $4{ }^{\circ} \mathrm{C}$ with 488- or 594-conjugated donkey secondary antibody (Invitrogen) and DAPI (Sigma-Aldrich). Omission of primary antibody served as the negative control. The following primary antibodies were used: anti- $\beta$-catenin (BD Biosciences), antimyosin VIIA (Myosin7a) (Proteus Biosciences, Ramona, CA, USA), anti-cleaved caspase-3 (Cell Signaling Technology), anti-Foxo3 (Cell Signaling Technology), antiParvalbumin (Sigma-Aldrich), TUNEL (Roche, Indianapolis, IN, USA), and MitoSOX Red (Life Technologies, Rockford, IL, USA). Cochleae were dissected into apical, middle, and basal turns, and images were taken using a Leica SP5 confocal fluorescence microscope (Leica Microsystems, Biberach, Germany).

Fluorescence activated cell sorting. Gfi1-Cre/ $\beta$-catenin ${ }^{\text {flox(exon2-6)/ }}$

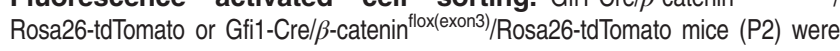
dissected out to isolate $\sim 20-40$ cochleae, and then trypsinized with prewarmed $0.125 \%$ trypsin/EDTA (Invitrogen) at $37^{\circ} \mathrm{C}$ for $8 \mathrm{~min}$. Soybean trypsin inhibitor (Worthington Biochem, Lakewood, CO, USA) was added to terminate the reaction followed by mechanical trituration with blunt tips and pipetting up and down up to 80-100 times. Suspended cells were percolated through a 40- $\mu \mathrm{m}$ cell strainer before fluorescence activated cell sorting (FACS). tdTomato-positive HCs were sorted out on a BD FACS Aria III (BD Biosciences) using the tdTomato channel.

Cell counts. For $\mathrm{HC}$ quantification in the neomycin-treated samples, we imaged the entire cochlea using a $40 \times 3$ objective and counted the Myosin7a+ HCs that remained. The same procedure was used to quantify cleaved caspase-3+/ Myosin7a+, TUNEL+/Myosin7a+ cells, and myosin7a+/MitoSOX Red+ cells. For all experiments, only one cochlea from each mouse was used for immunofluorescence and quantification. Thus, $n$ represents the number of mice examined.
Statistical analyses. Statistical analyses were conducted using Microsoft Excel and GraphPad Prism software (GraphPad Software, La Jolla, CA ,USA). Data were expressed as mean \pm S.E.M. ABR thresholds were analyzed by two-way ANOVA followed by a Newman-Keuls post hoc test. Immunofluorescence analysis was performed with a two-tailed, unpaired Student's $t$-test when comparing two groups or with a one-way ANOVA followed by a Dunnett's multiple comparisons test when comparing more than two groups. $P<0.05$ was considered as statistically significant.

\section{Conflict of Interest}

The authors declare no conflict of interest.

Acknowledgements. We wish to thank Jin Li and Yalin Huang of the Institutes of Biomedical Sciences of Fudan University for providing technical support with the confocal microscope. This work was supported by grants from the Major State Basic Research Development Program of China (973 Program) (2015CB965000), the National Natural Science Foundation of China (Nos. 81570911, 81470692, 81470687, $81371094,81230019,81500790,81570921,31500852$, and 31501194), the Jiangsu Province Natural Science Foundation (BK20150022, BK20140620, and BK20150598), the Program of Leading Medical Personnel in Shanghai, the Fundamental Research Funds for the Central Universities (2242014R30022, 021414380037), the Construction Program of Shanghai Committee of Science and Technology (12DZ2251700), the Major Program of Shanghai Committee of Science and Technology (14DJ1400203, 11441901000), the Doctoral fund of the Chinese Ministry of Education (20120071110077), and the China Postdoctoral Science Foundation Funded Project (2014M551328).

\section{Author contributions}

$\mathrm{HL}$ and $\mathrm{RC}$ conceived and designed the experiments. LL, YC, YZ, LW, WN, JQ, SZ, and YD performed the experiments. LL, YC, HL, RC, SS, MT, and WL analyzed the data. $\mathrm{LL}, \mathrm{YC}, \mathrm{RC}$, and $\mathrm{HL}$ wrote the paper.

1. Ohyama $T$, Mohamed OA, Taketo MM, Dufort D, Groves AK. Wnt signals mediate a fate decision between otic placode and epidermis. Development 2006; 133: 865-875.

2. Rakowiecki S, Epstein DJ. Divergent roles for Wnt/beta-catenin signaling in epithelial maintenance and breakdown during semicircular canal formation. Development 2013; 140: 1730-1739.

3. Jacques BE, Puligilla C, Weichert RM, Ferrer-Vaquer A, Hadjantonakis AK, Kelley MW et al. A dual function for canonical Wnt/beta-catenin signaling in the developing mammalian cochlea. Development 2012; 139: 4395-4404.

4. Shi F, Hu L, Jacques BE, Mulvaney JF, Dabdoub A, Edge AS. beta-Catenin is required for hair-cell differentiation in the cochlea. J Neurosci 2014; 34: 6470-6479.

5. Chai R, Kuo B, Wang T, Liaw EJ, Xia A, Jan TA et al. Wnt signaling induces proliferation of sensory precursors in the postnatal mouse cochlea. Proc Natl Acad Sci USA 2012; 109: 8167-8172.

6. Chai R, Xia A, Wang T, Jan TA, Hayashi T, Bermingham-McDonogh $O$ et al. Dynamic expression of Lgr5, a Wnt target gene, in the developing and mature mouse cochlea. J Assoc Res Otolaryngol 2011; 12: 455-469.

7. Cox BC, Chai R, Lenoir A, Liu Z, Zhang L, Nguyen D et al. Spontaneous hair cell regeneration in the neonatal mouse cochlea in vivo. Development 2014; 141: 816-829.

8. Shi F, Hu L, Edge AS. Generation of hair cells in neonatal mice by beta-catenin overexpression in Lgr5-positive cochlear progenitors. Proc Natl Acad Sci USA 2013; 110: 13851-13856.

9. Shi F, Kempfle JS, Edge AS. Wnt-responsive Lgr5-expressing stem cells are hair cell progenitors in the cochlea. J Neurosci 2012; 32: 9639-9648.

10. Jan TA, Chai R, Sayyid ZN, van Amerongen R, Xia A, Wang T et al. Tympanic border cells are Wnt-responsive and can act as progenitors for postnatal mouse cochlear cells. Development 2013; 140: 1196-1206.

11. Fragoso MA, Yi H, Nakamura RE, Hackam AS. The Wnt signaling pathway protects retinal ganglion cell 5 (RGC-5) cells from elevated pressure. Cell Mol Neurobiol 2011; 31: 163-173.

12. Liu X, Lu R, Wu S, Zhang YG, Xia Y, Sartor RB et al. Wnt2 inhibits enteric bacterial-induced inflammation in intestinal epithelial cells. Inflamm Bowel Dis 2012; 18: 418-429.

13. Lehwald N, Tao GZ, Jang KY, Sorkin M, Knoefel WT, Sylvester KG. Wnt-beta-catenin signaling protects against hepatic ischemia and reperfusion injury in mice. Gastroenterology 2011; 141: 707-718, e701-705.

14. Tao GZ, Lehwald N, Jang KY, Baek J, Xu B, Omary MB et al. Wnt/beta-catenin signaling protects mouse liver against oxidative stress-induced apoptosis through the inhibition of forkhead transcription factor FoxO3. J Biol Chem 2013; 288: 17214-17224.

15. Yang Y, Su Y, Wang D, Chen Y, Wu T, Li G et al. Tanshinol attenuates the deleterious effects of oxidative stress on osteoblastic differentiation via Wnt/FoxO3a signaling. Oxid Med Cell Longev 2013; 2013: 351895. 
16. Shen $L$, Zhang $X, H u D$, Feng $T$, Li H, Lu $Y$ et al. Hepatitis B virus $X(H B x)$ play an antiapoptosis role in hepatic progenitor cells by activating Wnt/beta-catenin pathway. Mol Cell Biochem 2013; 383: 213-222.

17. Yang Y, Mallampati S, Sun B, Zhang J, Kim SB, Lee JS et al. Wnt pathway contributes to the protection by bone marrow stromal cells of acute lymphoblastic leukemia cells and is a potential therapeutic target. Cancer Lett 2013; 333: 9-17.

18. Hagenbuchner J, Kuznetsov A, Hermann M, Hausott B, Obexer P, Ausserlechner MJ. FOXO3-induced reactive oxygen species are regulated by BCL2L11 (Bim) and SESN3. J Cell Sci 2012; 125(Pt 5): 1191-1203.

19. Yao H, Chung S, Hwang JW, Rajendrasozhan S, Sundar IK, Dean DA et al. SIRT1 protects against emphysema via FOXO3-mediated reduction of premature senescence in mice. J Clin Invest 2012; 122: 2032-2045.

20. Dansen TB, Burgering BM. Unravelling the tumor-suppressive functions of FOXO proteins Trends Cell Biol 2008; 18: 421-429.

21. Gargini R, Cerliani JP, Escoll M, Anton IM, Wandosell F. Cancer stem cell-like phenotype and survival are coordinately regulated Byakt/Foxo/Bim pathway. Stem Cells 2014; 33: 646-660.

22. Dehner M, Hadjihannas M, Weiske J, Huber O, Behrens J. Wnt signaling inhibits Forkhead box O3a-induced transcription and apoptosis through up-regulation of serum- and glucocorticoid-inducible kinase 1. J Biol Chem 2008; 283: 19201-19210.

23. Tao GZ, Lehwald N, Jang KY, Baek J, Xu B, Omary MB et al. Wnt/beta-catenin signaling protects mouse liver against oxidative stress-induced apoptosis through the inhibition of forkhead transcription factor FoxO3. J Biol Chem 2013; 288: 17214-17224.

24. Yang H, Gan J, Xie X, Deng M, Feng L, Chen X et al. Gfi1-Cre knock-in mouse line: a tool for inner ear hair cell-specific gene deletion. Genesis 2010; 48: 400-406.

25. Sun $\mathrm{S}$, Sun $\mathrm{M}$, Zhang $\mathrm{Y}$, Cheng $\mathrm{C}$, Waqas $\mathrm{M}$, Yu $\mathrm{H}$ et al. In vivo overexpression of $X$-linked inhibitor of apoptosis protein protects against neomycin-induced hair cell loss in the apical turn of the cochlea during the ototoxic-sensitive period. Front Cell Neurosci 2014; 8 : 248

26. Matsui Jl, Ogilvie JM, Warchol ME. Inhibition of caspases prevents ototoxic and ongoing hair cell death. J Neurosci 2002; 22: 1218-1227.

27. Sun S, Yu H, Honglin M, Ni W, Zhang $Y$, Guo $L$ et al. Inhibition of the activation and recruitment of microglia-like cells protects against neomycin-induced ototoxicity. Mol Neurobiol 2014; 51: 252-267.

28. Dehner M, Hadjihannas M, Weiske J, Huber O, Behrens J. Wnt signaling inhibits Forkhead box O3a-induced transcription and apoptosis through up-regulation of serum- and glucocorticoid-inducible kinase 1. J Biol Chem 2008; 283: 19201-19210.

29. Marinkovic D, Zhang X, Yalcin S, Luciano JP, Brugnara C, Huber T et al. Foxo3 is required for the regulation of oxidative stress in erythropoiesis. J Clin Invest 2007; 117: 2133-2144.

30. Choung YH, Taura A, Pak K, Choi SJ, Masuda M, Ryan AF. Generation of highly-reactive oxygen species is closely related to hair cell damage in rat organ of Corti treated with gentamicin. Neuroscience 2009; 161: 214-226.

31. Liu J, Cao L, Chen J, Song S, Lee IH, Quijano C et al. Bmi1 regulates mitochondrial function and the DNA damage response pathway. Nature 2009; 459: 387-392.

32. Du H, Guo L, Fang F, Chen D, Sosunov AA, McKhann GM et al. Cyclophilin D deficiency attenuates mitochondrial and neuronal perturbation and ameliorates learning and memory in Alzheimer's disease. Nat Med 2008; 14: 1097-1105.

33. Yousefi S, Mihalache C, Kozlowski E, Schmid I, Simon HU. Viable neutrophils release mitochondrial DNA to form neutrophil extracellular traps. Cell Death Differ 2009; 16 1438-1444.

34. Demols A, Van Laethem JL, Quertinmont E, Legros F, Louis H, Le Moine $\mathrm{O}$ et al. $\mathrm{N}$-acetylcysteine decreases severity of acute pancreatitis in mice. Pancreas 2000; 20: 161-169.

35. Wang Z, Ma LJ, Kang Y, Li X, Zhang XJ. Dickkopf3 (Dkk3) induces apoptosis in cisplatinresistant lung adenocarcinoma cells via the Wnt/betacatenin pathway. Oncol Rep 2015; 33: 1097-1106.

36. Hsu HC, Liu YS, Tseng KC, Tan BC, Chen SJ, Chen HC. LGR5 regulates survival through mitochondria-mediated apoptosis and by targeting the Wnt/beta-catenin signaling pathway in colorectal cancer cells. Cell Signal 2014; 26: 2333-2342.
37. Cardaci S, Filomeni G, Rotilio G, Ciriolo MR. Reactive oxygen species mediate p53 activation and apoptosis induced by sodium nitroprusside in SH-SY5Y cells. Mol Pharmaco 2008; 74: 1234-1245.

38. Huang J, Wu L, Tashiro S, Onodera S, Ikejima T. Reactive oxygen species mediate oridonininduced HepG2 apoptosis through p53, MAPK, and mitochondrial signaling pathways. J Pharmacol Sci 2008; 107: 370-379.

39. Tsang WP, Chau SP, Kong SK, Fung KP, Kwok TT. Reactive oxygen species mediate doxorubicin induced p53-independent apoptosis. Life Sci 2003; 73: 2047-2058.

40. Hayashi $\mathrm{Y}$, Yamamoto $\mathrm{N}$, Nakagawa $\mathrm{T}$, Ito J. Insulin-like growth factor 1 induces the transcription of Gap43 and Ntn1 during hair cell protection in the neonatal murine cochlea. Neurosci Lett 2014; 560: 7-11.

41. Kim SJ, Lim JY, Lee JN, Choe SK, Kim YI, Song SR et al. Activation of beta-catenin by inhibitors of glycogen synthase kinase-3 ameliorates cisplatin-induced cytotoxicity and proinflammatory cytokine expression in HEl-OC1 cells. Toxicology 2014; 320: 74-82.

42. Huang T, Cheng AG, Stupak H, Liu W, Kim A, Staecker H et al. Oxidative stress-induced apoptosis of cochlear sensory cells: otoprotective strategies. Int J Dev Neurosci 2000; 18 : 259-270.

43. Veeman MT, Axelrod JD, Moon RT. A second canon. Functions and mechanisms of betacatenin-independent Wnt signaling. Dev Cell 2003; 5: 367-377.

44. Kohn AD, Moon RT. Wnt and calcium signaling: beta-catenin-independent pathways. Cell Calcium 2005; 38: 439-446.

45. Esterberg R, Hailey DW, Coffin AB, Raible DW, Rubel EW. Disruption of intracellular calcium regulation is integral to aminoglycoside-induced hair cell death. $J$ Neurosci 2013; 33: 7513-7525.

46. Gorlach A, Bertram K, Hudecova S, Krizanova O. Calcium and ROS: a mutual interplay. Redox Biol 2015; 6: 260-271.

47. Wei L, Ding L, Mo MS, Lei M, Zhang L, Chen $\mathrm{K}$ et al. Wnt3a protects SH-SY5Y cells against 6-hydroxydopamine toxicity by restoration of mitochondria function. Transl Neurodegener 2015; $4: 11$.

48. Yoon JC, Ng A, Kim BH, Bianco A, Xavier RJ, Elledge SJ. Wnt signaling regulates mitochondrial physiology and insulin sensitivity. Genes Dev 2010; 24: 1507-1518.

49. Harada N, Tamai Y, Ishikawa T, Sauer B, Takaku K, Oshima M et al. Intestinal polyposis in mice with a dominant stable mutation of the beta-catenin gene. EMBO J 1999; 18 5931-5942.

50. Brault V, Moore R, Kutsch S, Ishibashi M, Rowitch DH, McMahon AP et al. Inactivation of the beta-catenin gene by Wnt1-Cre-mediated deletion results in dramatic brain malformation and failure of craniofacial development. Development 2001; 128: 1253-1264.

51. Madisen L, Mao T, Koch H, Zhuo JM, Berenyi A, Fujisawa S et al. A toolbox of Credependent optogenetic transgenic mice for light-induced activation and silencing. Nat Neurosci 2012; 15: 793-802.

52. Parker M, Brugeaud A, Edge AS. Primary culture and plasmid electroporation of the murine organ of Corti. J Vis Exp 2010; 36: 1685.

53. Wang J, Menchenton T, Yin S, Yu Z, Bance M, Morris DP et al. Over-expression of X-linked inhibitor of apoptosis protein slows presbycusis in C57BL/6J mice. Neurobiol Aging 2010; 31: $1238-1249$.

(i) Cell Death and Disease is an open-access journal published by Nature Publishing Group. This work is licensed under a Creative Commons Attribution 4.0 International License. The images or other third party material in this article are included in the article's Creative Commons license, unless indicated otherwise in the credit line; if the material is not included under the Creative Commons license, users will need to obtain permission from the license holder to reproduce the material. To view a copy of this license, visit http://creativecommons.org/licenses/by/4.0/ 